\title{
HUDSON BAY SEA-FLOOR PHOTOGRAPHS
}

\author{
F.G. BARBER \\ Department of Fisheries and Oceans, Ottawa, CANADA KIA OE6 \\ E.H. GRAINGER \\ Department of Fisheries and Oceans, Arctic Biological Station \\ Ste Anne de Bêllevue, Quebec, CANADA H9X 3R4 \\ B.R. PELLETIER \\ Department of Energy, Mines and Resources, Geological Survey of Canada, Ottawa, CANADA KIA OE 8
}

\begin{abstract}
A variety of bottom dwelzers and some aspects of their interaction with habitat, as in lebensspuren, and with other animals are seen in photographs of the floor of Hudson Bay. The influence of ice-rafting on sediment type and distribution is depicted.
\end{abstract}

\section{INTRODUCTION}

The program of oceanographic survey of Hudson Bay in 1961 aboard MY THETA included the utilization of a then recently developed system for sea-floor photography (Edgerton 1964). Camera stations were occupied at eight locations in Hudson Bay, at depths ranging from 55 to $183 \mathrm{~m}$. Photographs from five of these stations (Fig. 1) are given here. Although many of these photographs have been published in various accounts (anon. 1964, Leslie 1965, Leslie and Pelletier 1965, Barber 1967, 1968, Grainger 1968, Pelletier, Wagner, and Grant 1968), it does not appear that the photographs have proved of particular interest or use. According to Fell (1967) this may not be unusual. However at the recent Hudson Bay Symposium held at the University of Guelph (April 28-30, 1981) we exhibited many of these photographs and found considerable interest in them by the visitors. It was generally felt amongst the biologists that photography may be a necessary tool to employ if we are to progress our understanding of benthic communities (e.g. Ellis 1976) and their ecology. Certainly it is a valuable aid to the geologist in understanding the environment of deposition, particularly the hydrodynamic conditions. that may be observed in the photographs. Such evidence may assist the geologist in deducing agents and routes of sediment transport by examining the texture and shape of substrate material.

\section{METHODS}

The Edgerton cameras were mounted in stereopair on a metal frame that also supported a light source, and a sound source (sonar pinger) for determining elevations above the seabed (Fig. 2). Tri X film was used because it would provide better resolution of small-scale bottom features. While on station and the camera was suspended over the seabed, the ship was permitted to drift for periods of 30 to 60 minutes. Station data were recorded by means of inset photography in that each negative included the following information per photograph (see App. 13): film type, date, organization, ship, station number, ship's name, cruise designation, left or right camera, number of frame, number of camera lowering, longitude and latitude, an inset showing water depth in metres, and a clock showing time of day. Prints are presently available through the first author (FGB) (Fisheries and Oceans Canada, 240 Sparks Street, Ottawa, Ontario, Canada, KlA OE8).

\section{THE PHYSICAL ENVIRONMENT}

Hudson Bay and approaches are part of a continuous inland sea lying in northeastern Canada between latitudes 55 and 65 north, and longitudes 75 and 95 west. Its seafloor comprises a saucershaped basin, interrupted by a structural arch extending northerly from the southern shore just west of James Bay (Fig. 3). This arch ends in a feature called Midbay Bank. lying in 30 to $40 \mathrm{~m}$ of water, and separates the seabed into two major basins which coalesce in the north at depths of 180 to $240 \mathrm{~m}$. Midbay Bank was noted by Leslie and Pelletier (1965), who also related the nature of the bedrock beneath Hudson Bay to its morphological features. Much of this was confirmed by the results of seismic investigations undertaken by Grant (1969), and the geological mapping completed by Sanford et al (1978). An ancient radial drainage system (Fig. 3) was distinguished by Pelletier (1966, 1968, 1969), but its age is unknown. Several major morphological features have been identified, located, and named on a regional map constructed by Sanford and Grant (1977).

Oceanographic features in Hudson Bay were described earlier by Hachey $(1931,1935)$, Barber and Glennie (1964), and Barber (1967). In this report only a brief account of summer oceanography is given and is summarized in the maps of bottom temperatures (Fig. 4), dissolved oxygen content in bottom waters (Fig. 5), and salinity of bottom waters (Fig. 6). Oceanic circulation is counterclockwise, and is part of the driving mechanism for moving coastal ice and its rafted sediment component around the seaward perimeter of the bay (Fig. 7, 8).

Types of bottom sediments are characteristically associated with depth of water and distance from shore Fig. 9, in that coarse sands and gravels lie along adjacent coasts and shelves to $80 \mathrm{~m}$ depth approximately and finer sands, silts, and clays occur progressively further offshore. In the deeper basins and lower submarine slopes in Hudson Bay only the finest silts and clays are deposited by marine currents, although some coarser ice-rafted debris may be deposited there. Ice-rafting, however, is generally common over the entire inner portion of the bay. Much of it is modern and is derived locally. However older ice-rafted material was transported westerly from Labrador, and easterly from Keewatin according to Shilts (1981) who has drawn new flow lines of Pleistocene ice movement across Hudson Bay. Branches of the main ice streams join near Midbay shoal and flow north. Some of this work has been confirmed by Adshead (1981) in mineralogical and geochemical studies on estuarine samples from the west 


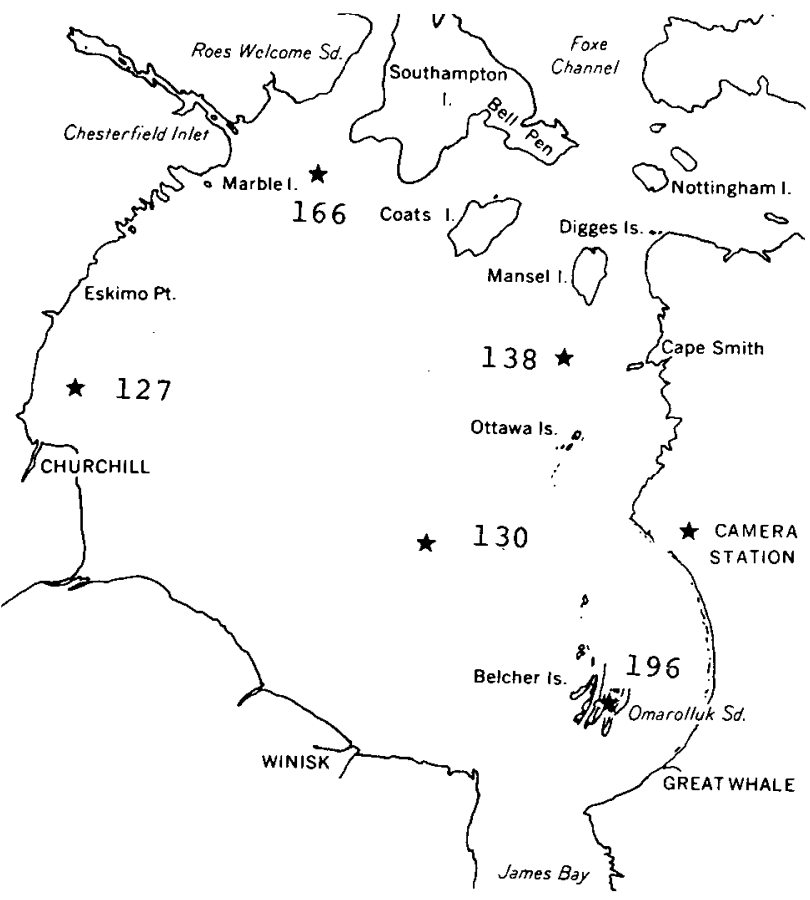

FIG. 1 Locator map of camera stàtions in Hudson Bay during crulse of MV THETA in 1961. Photographs were obtained at five sites in depths ranging from 55 to $183 \mathrm{~m}$. Depths are given in parentheses for respective stations: station $127(64 \mathrm{~m}), 130(183 \mathrm{~m})$, $138(104 \mathrm{~m}), 166(75 \mathrm{~m})$, and $196(55 \mathrm{~m})$.

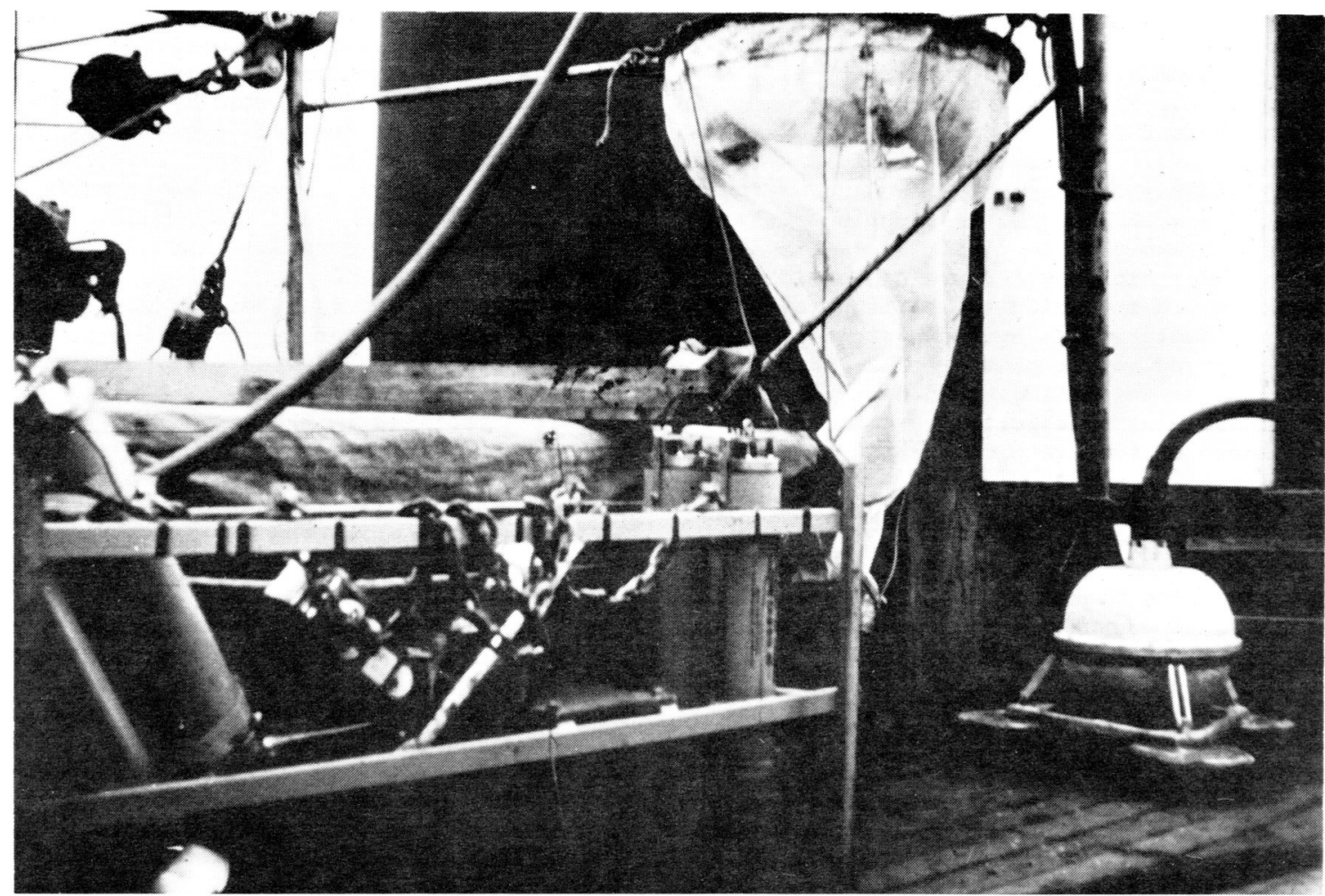

FIG. 2 The Edgerton (1964) camera system comprising a light source attached on the left end of the frame shown, a sound source (sonar pinger) mounted in the middle of the camera frame, and two $35 \mathrm{~mm}$ cameras mounted vertically at the right end of the frame. Plankton net hanging to right of cameras, coring tube lashed to deck stanchion in rear, and bottom gravimeter on deck at extreme right were employed on cruise. 


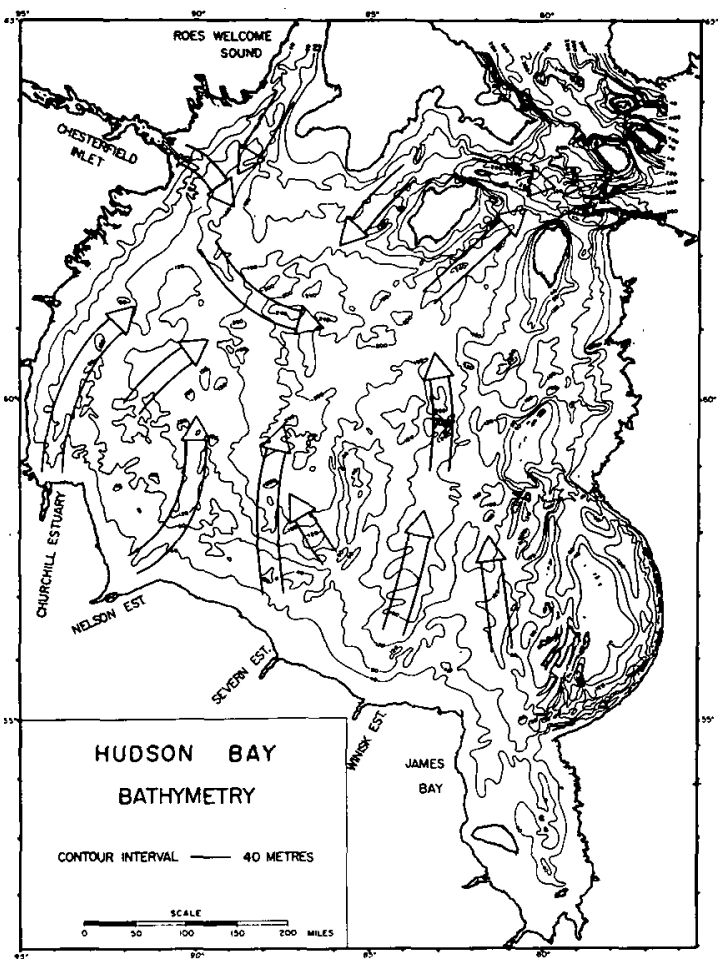

FIG. 3 Sea-floor morphology of Hudson Bay showing concentric contours and protruberances of Midbay Bank north of Winisk Estuary. Arrows represent interpretation of ancient drainage pattern (Pelletier, 1969).

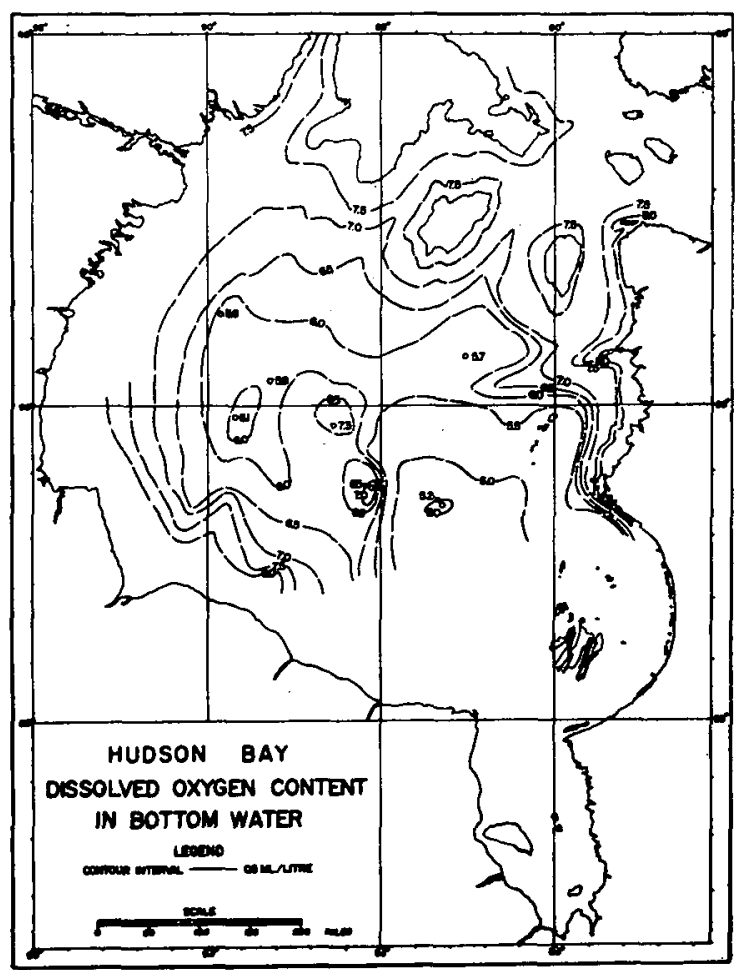

FIG. 5 Dissolved ox gen content in Hudson Bay bottom water ranges from $5.0 \mathrm{ml} / /$ in deep water, to $8.5 \mathrm{ml} / /$ in shallow water. No real deficiency of oxygen in bottom waters occurs anywhere in the bay (Pelletier 1969).

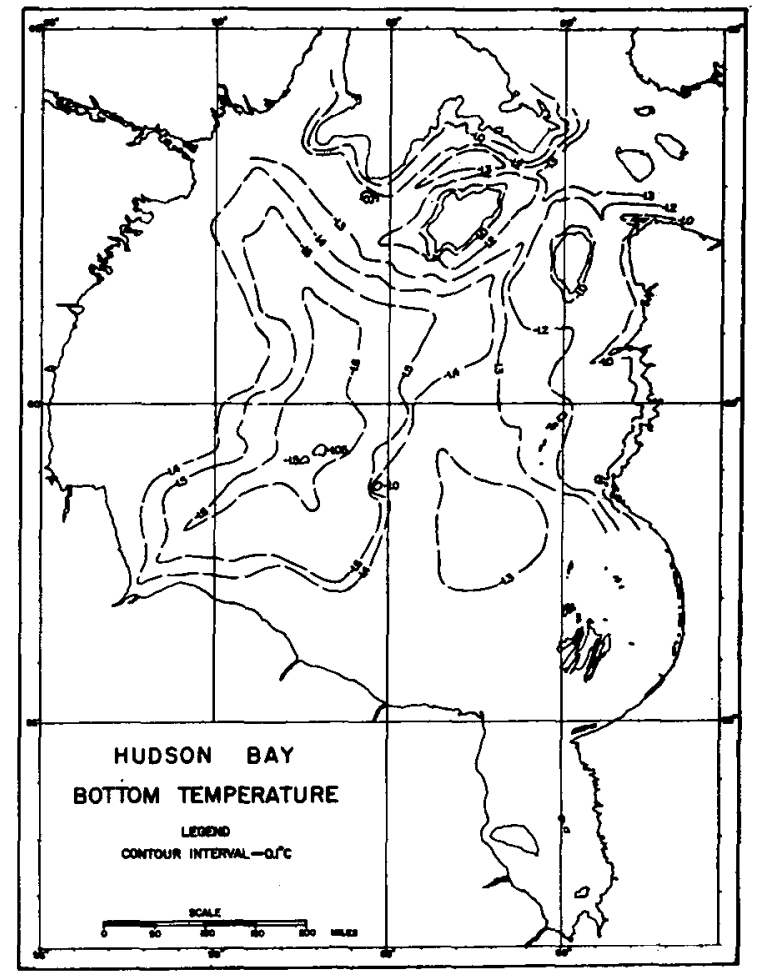

FIG. 4 Bottom temperatures shown here for Hudson Bay during the summer are generally negative. Deeper waters are usually colder (Pelletier, 1969).

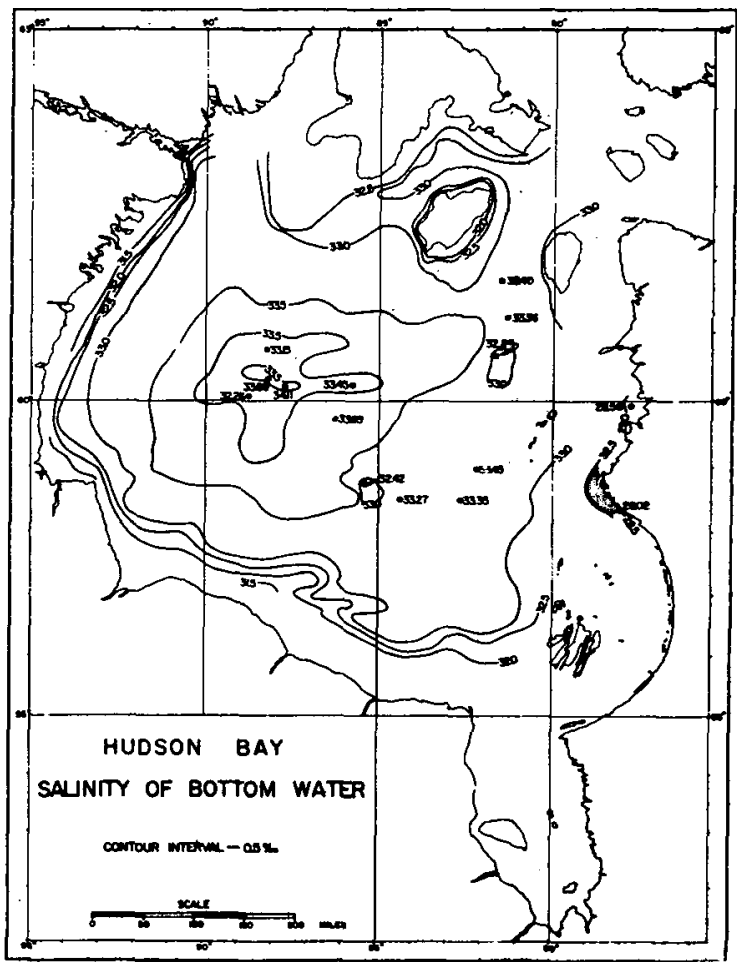

FIG. 6 Salinities in bottom waters in Hudson Bay are given here, and range from $0.5 \%$ /oo (parts per thousand) to 34.11 o/oo. Lowest salinities occur near shore due to influence of fresh water from streams. Highest salinities are in the deeper, central areas. (Pelletier 1969). 

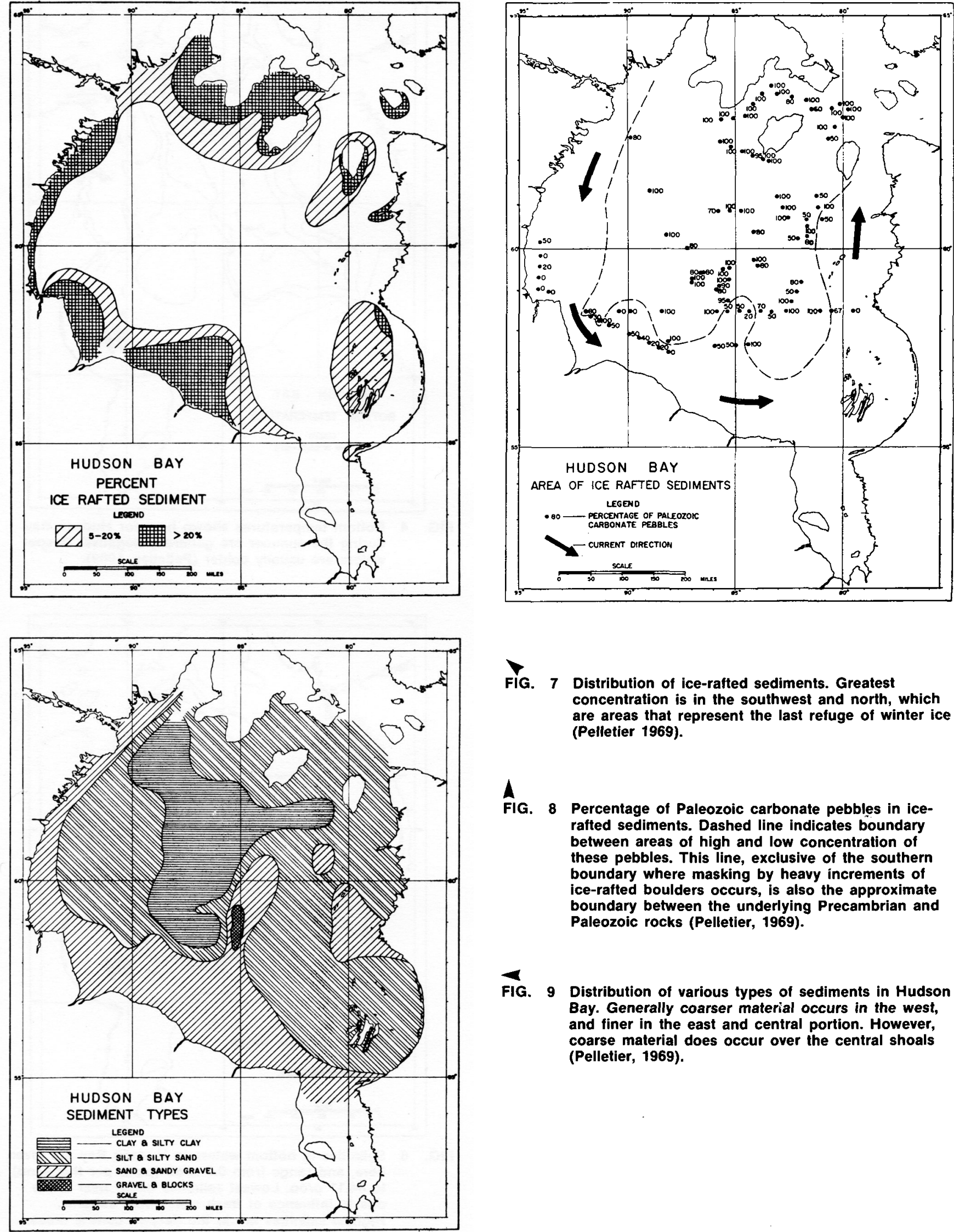

FIG. 7 Distribution of ice-rafted sediments. Greatest concentration is in the southwest and north, which are areas that represent the last refuge of winter ice (Pelletier 1969).

$\Lambda$

FIG. 8 Percentage of Paleozoic carbonate pebbles in icerafted sediments. Dashed line indicates boundary between areas of high and low concentration of these pebbles. This line, exclusive of the southern boundary where masking by heavy increments of ice-rafted boulders occurs, is also the approximate boundary between the underlying Precambrian and Paleozoic rocks (Pelletier, 1969).

FIG. 9 Distribution of various types of sediments in Hudson Bay. Generally coarser material occurs in the west, and finer in the east and central portion. However, coarse material does occur over the central shoals (Pelletier, 1969). 
side of Hudson and James Bays; and by Shilts who examined the petrography of the pebbles obtained in bottom dredge samples supplied by C.F.M. Lewis and B.V. Sanford of the Geological Survey of Canada.

\section{SOME PURPOSES OF SEA-FLOOR PHOTOGRAPHY}

Of great potential interest to students of benthic features are sea-floor photographs; their clarity can be superb (see Appendix), and splendid detail can be revealed in stereograms (Appx. 5 and 6). Their usefulness is not so much that they show identity and number of individuals (better assessments of this kind can usually be made from collected material), but rather that they reveal movements, postures, and relationships, thus supporting the notion that photography may be necessary to understanding bottom communities (Ellis 1976). However, in the absence of direct evidence and in the knowledge that physical processes, for example falling and rolling cobbles and boulders can produce animal-like trails, one must exercise caution when interpreting sea-floor photographs (Ewing and Davis 1967).

Fortunately there are other observations involving fewer hazards in these photographic interpretations. Animals and plants may be identified to various levels of taxonomic precision, depending partly on the clarity of the photography, partly on the position of the organism, and partly on the prominence of structures used in identification. We may see such spatial associations as those between animals and sheltering rocks, and between animals and holes in the substrate. Spatial relations between densely packed brittle stars, or among members of crowded groups of unrelated species sharing small, isolated rocky patches can be observed. Movement of worms are indicated by marks of soft substrates, and movements of brittle stars are deduced by noting the positions of their rays. An interesting posture shown by some crabs, with anterior body raised and forward legs slightly uplifted is apparent in some of the photographs. Ophiuroids show horizontally oriented postures indicating movement along the bottom; also, they may show different positioning of rays, which indicates other activities such as feeding.

crinoids and commonly brittle stars show alignment of rays suggesting a response to water movement and currents (including tidal motions). This hydrodynamic vigour can create visible areas of deposition and scour among boulders. Other evidence of water motion may be observed in the formation of ripple marks and sand waves.

Fields of large cobbles and blocks indicate the occurrence of ice-rafting (App. 1, 3-10). Much of this larger component of the substrate has been deposited by sea ice that has incorporated the sediment in the intertidal zone, or somewhat below it, and carried the material well offshore. The rounded triangular-shaped boulders and pebbles are characteristic of glacial transport on land. Some of this debris has been carried offshore by sea ice, although much of this material now found on the Hudson Bay sea floor is a result of ice-rafting by means of the continental ice sheets. Angular blocks with sharp edges generally indicate local derivation. Parts of Hudson Bay (the shallow portions) are underlain directly by bedrock, and bedrock is also exposed along the coast; therefore, numerous sources of this fresh material exist. Sea-floor photography of such detritus, both the remotely and locally derived, may assist in deducing the direction of sediment transport, sources of supply, and the flow direction of the ice.

\section{RESULTS}

Sponges (Porifera) appear in greater apparent diversity than available published accounts indicate; however, none of the larger collections of sponges from Hudson Bay has been studied and only a single species has been reported (Dendy and Frederick 1924). Among the Cnidaria, the anemones (Actiniaria) are another group about which surprisingly little is known in Hudson Bay; Verrill (1922) reported only four species. Several appear at the same stations as the sponges. Octocorals (Alcyonaria) have been found to include three species in Hudson Bay (unpublished records of the Arctic Biological Station); The most common, Gersemia rubiformis, appears at station 166 (App. 4). There are at least 57 species of polychaetonous annelids in the bay according to Berkeley and Berkeley (1943). Only one is identifiable in our photos; Onuphis, a mobile tube-dweller, makes conspicuous lebensspuren of fine sediments (App, 2). Bryozoans are numerous in Hudson Bay, from where more than 30 species have been collected (Osburn 1932, Powell 1968); several unidentified forms are visible in the photographs. At least 62 bivalve molluses (Pelecypoda) have been collected in Hudson Bay (Lubinsky 1980). Whole single shells and many fragments may be seen in most photos at stations 12 (App. 1), 138 (App. 3, 7-10) and 166 (App. 4). Macpherson (1971) listed more than 30 gastropod species collected in the bay, but only a single snail appears in the photographs.

Decapod crustaceans number at least 13 species, according to Squires (1967). Crabs (Hyas coarctatus) are seen in a number of photos; one may be taking shelter under the edge of a rock (App. I). It is speculated that the holes shown in the fine substrate may be associated with crabs. In one photo, a shrimp (station 196, App. 11, 12), evidently a crangonid, is seen resting on the soft substrate. Echinoderms are represented by several organisms: crinoids (Heliometre glacialis) appear frequently (station 166, App. 4) while brittle stars (Ophiuroidea) are very obvious in photographs from most stations; indeed they are the most abundant of the visible animals. Six species, of the three genera Ophiura, Ophiocten and Ophiopholis, are reported from Hudson Bay collections (Clark 1937). Sea stars (Asteroidea) photographed include Urasterias Lincki (Station, 130, App. 2) one of the 11 species known from Hudson Bay collecttons (Grainger 1966). The only sea urchin (Echinoidea) photographed in Hudson Bay and reported from collections is Strongyzocentrotus droebachiensis. A single ascidian species is seen; it is the upright, stalked Boltenia ovifera, reported from Hudson Bay collections by Trason (1964).

Fish are seen only infrequently, but several photographs show a sinuous fish, probably Lumpenus fabmicii the slender eelblenny. This and another species of the genus are recorded among 31 marine species coilected in Hudson Bay (Hunter 1968). The slender eelblenny, of the family of pricklebacks, could be responsible for the nest-like feature 
frequently seen at station 138 (App. 7-10). Another member of the family, the high cockscomb, is known to guard egg masses at the nest (to defend a territory) and to fan the eggs by body movement (Hart 1973, p. 330). This could create the area of reduced sediment over the nest-like sites suggested by the photographs.

Much of the material utilized for the nest-like features appears to be ice-rafted, for rafting by the annual cover of ice is known to contribute significantly to the sediment in the bay (Leslie 1964, Pelletier et al 1968). At station 138 (south of Mansel Island and west of Cape Smith) the larger of the ice-rafted boulders may show evidence of glacial action (App. 3) while the sediment surface immediately adjacent to the larger boulder indicates deposition by a northerly flowing current. Whether this current occurs to the bottom there throughout the year or is seasonal, is not known; present understanding suggests that it would likely be most pronounced in autumn.

Ice-rafted cobbles and boulders are readily identified, particularly those recently ice-rafted (as in App. 1, 3-10). and in a small number of photographs at one station (127) there is evidence of icerafted plant material. As sea weed is not an abundant feature of intertidal Hudson Bay, it is unlikely that ice transport of macroalgae contributes significantly to the trophic status of bottom dwellers there.

\section{DISCUSSION}

Although bottom photographs are helpful in studying and recording different species residing on the sea floor, most benthic animals are infaunal (inhabit the substrate) and may not be observable readily from the surface. Therefore they are missing from, or only incompletely shown in our photographs. The epifaunal element is what we see for the most part. However it is commonly elusive; it may move rapidly or seek shelter so that we may be unable to observe it in its entirety. This deficiency will be greatest in short surveys. The method, therefore, is not one to use in order to determine species composition of the bottor fauna. With knowledge of the species selected, however, it could be used for number estimates of certain epibenthic animals. There are nearly 300 benthic animal species known from Hudson Bay, but we have identified no more than 10 percent of them in bottom photographs.

The main value of the photographs for biological studies lies in what they show of relationships, that is to the substrate, to other animals and plants, and to moving water. They can show us the patterns of distribution of certain epibenthic species, and the degree to which individuals may be associated with particular bottom conditions. These patterns may be patchy or on a small scale that is too finely structured to be detected by dredging. The photographs may show us spatial relationships of different species, various forms of species interactions (between animals, and animals and plants), which may also be obscured in dredge samples. They may show, often with great clarity, various postures assumed by bottom animals, denoting a number of activities such as grasping, burrowing, boring, eluding predators, (seeking shelter), actively feeding (predatory activities) or passively (filter) feeding. There is potentially a great amount of information to be obtained in this way, which is almost invariably lost when one is forced to rely entirely on captured animals. Similar comments may be applied to geological studies. Large-scale features such as sand waves, moraines, ice-scoured grooves, and terraces that are easily observed on echograms and side scan sonargrams cannot be viewed in their entirety in singleframed bottom photographs. However for small-scale features, such as ripple marks, current scour, sediment deposits, or bedrock outcrop, bottom photographs are an immense aid in understanding the physical environment, the nature of the substrate, and the relationships of substrate elements to themselves as well as to the environment.

Because of the occurrence of Pleistocene glaciers over the area of present Hudson Bay (Leslie 1965, Pelletier 1969, Shilts 1981, Adshead 1981), photographs of boulders and rock fragments are significant in revealing some of this history. This is exemplified in the photographs at site 138 located north of the Belcher Islands. A rock fragment characterized by stromatolitic structure may have been derived from a similar rock outcropping on the Belcher Islands (J.A. Donaldson, Pers. Comm. also in a paper at the Guelph Symposium 1981 by J.A. Donaldson and C. Kari (1981). Shilts (1981) also showed Pleistocene iceflow directions that were traced north of the Belcher Islands and, thus, these photographs offer some evidence to support his postulations.

By far the most important sedimentological aspect of the seabed photographs lies in the fact that grain size can be observed, and inferences made on the hydrodynamic vigour at the depositional site. The soft clay occurring in the deeper parts of the bay have settled in a quiescent environment. In shallower parts, current-scoured pebble beds also reflect the hydrodynamic environment; in this case, its considerable vigour. Trails and mounds of sediments around pebbles have also been created by sediment transport induced by vigorous bottom currents. In many cases piston or gravity corers, as well as bottom grabbers, would be unable to recover such materials and, indeed, would be unable to record their occurrences and relationships to their environment. It is impossible to say that any suite of bottom photographs are representative of the entire seafloor. But because so many consecutive frames are similar at a given site, at least we may say that each series of bottom photographs are representative of that particular site. Therefore such camera surveys are most reliable in that aspect and serve in elucidating natural phenomena occurring on the seabed.

\section{ACKNOWLEDGEMENTS}

We thank Mr. J.E. Whittecker who operated and maintained the camera system in the field. We also thank our unknown reviewers for their comments on an earlier manuscript, and we appreciate the generosity of Dr. I. Peter Martini, Chairman of the Guelph Symposium on Hudson/James Bay who made the reviewers comments available to us. We have incorporated their suggestions, and have attempted to take note of our original deficiencies. Finally we offer our gratitude to the many delegates at the Guelph Symposium who visited our display, and engaged us in fruitful discussion regarding bottom photography and the natural phenomena in Hudson Bay. 


\section{REFERENCES}

ADSHEAD, J.D. 1981. Fluvial sand composition, drift provenance, and iceflow relationships in the Hudson Bay area, in Hudson/James Bay Symposium, University of Guelph, April 1981, Abstract, p. 1 .

ANONYMOUS, 1964. Data record, Hudson Bay Profect 1961. Department of Fisheries and Oceans, Canadian Oceanographic Data Centre Series 1, $173 \mathrm{pp}$.

BARBER, F.G. 1967. A contribution to the oceanography of Hudson Bay, Department of Energy, Mines and Resources, Marine Sciences Branch, ottawa, Canada, Manuscript report 4, $69 \mathrm{pp}$.

BARBER, F.G. 1968. The water of Hudson Bay. In C.S. Beals (ed), Science, History and Hudson Bay, pp 287-318.

BARBER, F.G. and GLENNIE, C.J. 1964. On the oceanography of Hudson Bay, an atlas presentation of data obtained in 1961. Canadian Department of Mines and Technical Surveys, Marine Sciences Branch, Manuscript Report, Series No. 1.

BERKELEY, E. and BERKELEY, C. 1943. Polychaeta from Hudson Bay. Journal of Fisheries Research Board Canada, vol. 6; pp. 129-132.

CLARK, A.H. 1937. Biological and oceanographic conditions in Hudson Bay II. Echinoderms of Hudson Bay. Journal of Fisheries Research Board Canada. vol. 3, pp. 350-357.

DENDY, A. and FREDERICK. 1924. Porifera. Report of the Canadian Arctic Expedition, 1913-18, $9(\mathrm{~J}), 8 \mathrm{pp}$.

HUNTER, J.G. 1968. Fishes and fisheries. In Science, History and Hudson Bay, C.S. Bealer (ed.). Department of Energy, Mines and Resources Canada, pp 360-378.

LESLIE, R.J. 1965. Sedimentology of Hudson Bay, District of Keewatin. Geological Survey of Canada Paper 63-48, 31 pp.

LESLIE, R.J. and PELLETIER, B.R. 1965. Bedrock geology beneath Hudson Bay as interpreted from submarine physiography; Bedford Institute of Oceanography Report 65-12.

LUBINSKY, I. 1972. Canadian Arctic marine bivalve molluscs. Ph.D Thesis, McGill University, Montreal, Quebec. $345 \mathrm{pp}$.
MACPHERSON, E. 1971. The marine molluses of Arctic Canada. National Museum Publication, Biological Oceanography no. 3, $149 \mathrm{pp}$.

OSBURN, R.C. 1932. Biological and oceanographic conditions in Hudson Bay. in Bryozoa from Hudson Bay and Strait. Contribution of Canadian Biol. Fish, Nova Scotia. no. 7 pp. 361-376.

PELLETIER, B.R. 1966. Bathymetry and geology of Hudson Bay and approaches. In Encyclopedia of Earth Sciences, Rhodes Fairbridge (ed.), Rheinhold Publishing Company, vol. 1.pp. 359363.

PELLETIER, B.R. 1969. Submarine physiography, bottom sediments, and models of sediments, and models of sediment transport in Hudson Bay. In Earth Sciences Symposium on Hudson Bay, P.J. Hood (ed.), Geological Survey of Canada Paper 68-53, pp. 100-135.

PELLETIER, B.R., WAGNER, F.J.E., and GRANT, A.C. 1968. Marine geology. In C.S. Beals (ed.) Science History and Hudson Bay, pp. 567-613.

SANFORD, B.V. and GRANT, A.C. 1977. PhysiographyEastern Canada and Adjacent Areas. Geological Survey of Canada Map 1399A.

SANFORD, B.V., GRANT, A.C., WADE, J.A., and BARSS, M.S. 1978. Geology - Eastern Canada and Adjacent Areas. Geological Survey of Canada Map $1401 \mathrm{~A}$.

SHILTS, W.W. 1981. Quaternary evolution of the Hudson/James Bay region. In Hudson/James Bay Symposium, University of Guelph, April, 1981. Abstract, p. 18.

SQUIRES, H.J. 1967. Decapod crustacea from CALANUS collections in Hudson Bay in 1953, 1954, and 1958-61. Journal of Fisheries Research Board Canada; vol. 24, pp. 1873-1903.

TRASON, W. 1964. Ascidians of the Canadian Arctic waters. Journal of Fisheries Research Board, vol. 21, pp. 1.505-1517.

VERRILI, A.E. 1922. Alcyonaria and Actinaris. Report of the Canadian Arctic Expedition, $1913-18,8(G), 165 \mathrm{pp}$. 
APPENDIX 1

Station 127 in $64 \mathrm{~m}$. Generally fine sediment with several pebbles, a recently rafted boulder, holes possibly due to burrowing animals, two crabs (Hyas) and litter (broken clam shells) lying adjacent to the clean cobble which appears to be sheltering a crab.

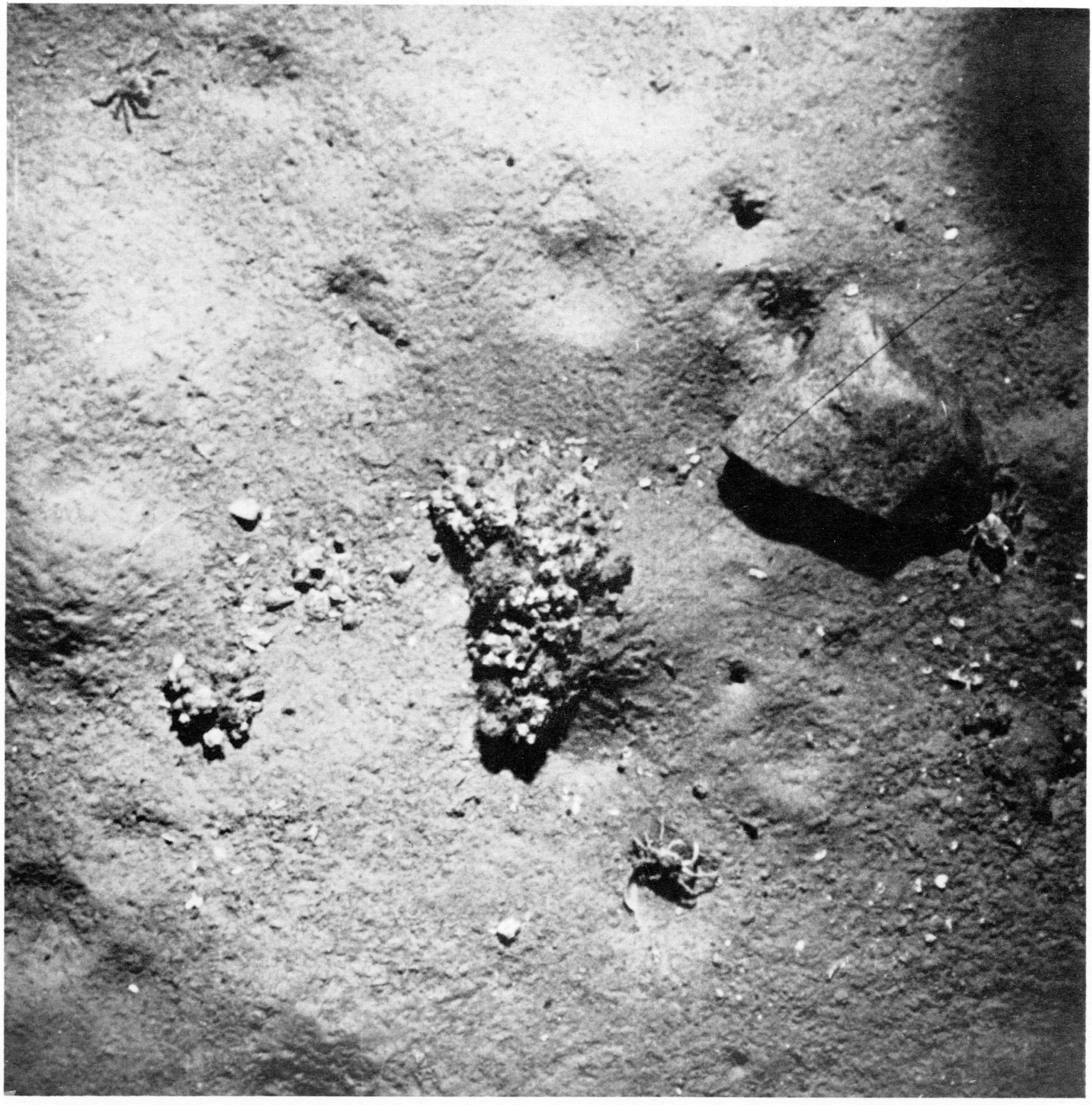




\section{APPENDIX 2}

Station 130 in $183 \mathrm{~m}$. Generally fine sediment with numerous animal traits (lebensspuren), polychaetes, and sea stars (Urasterias).

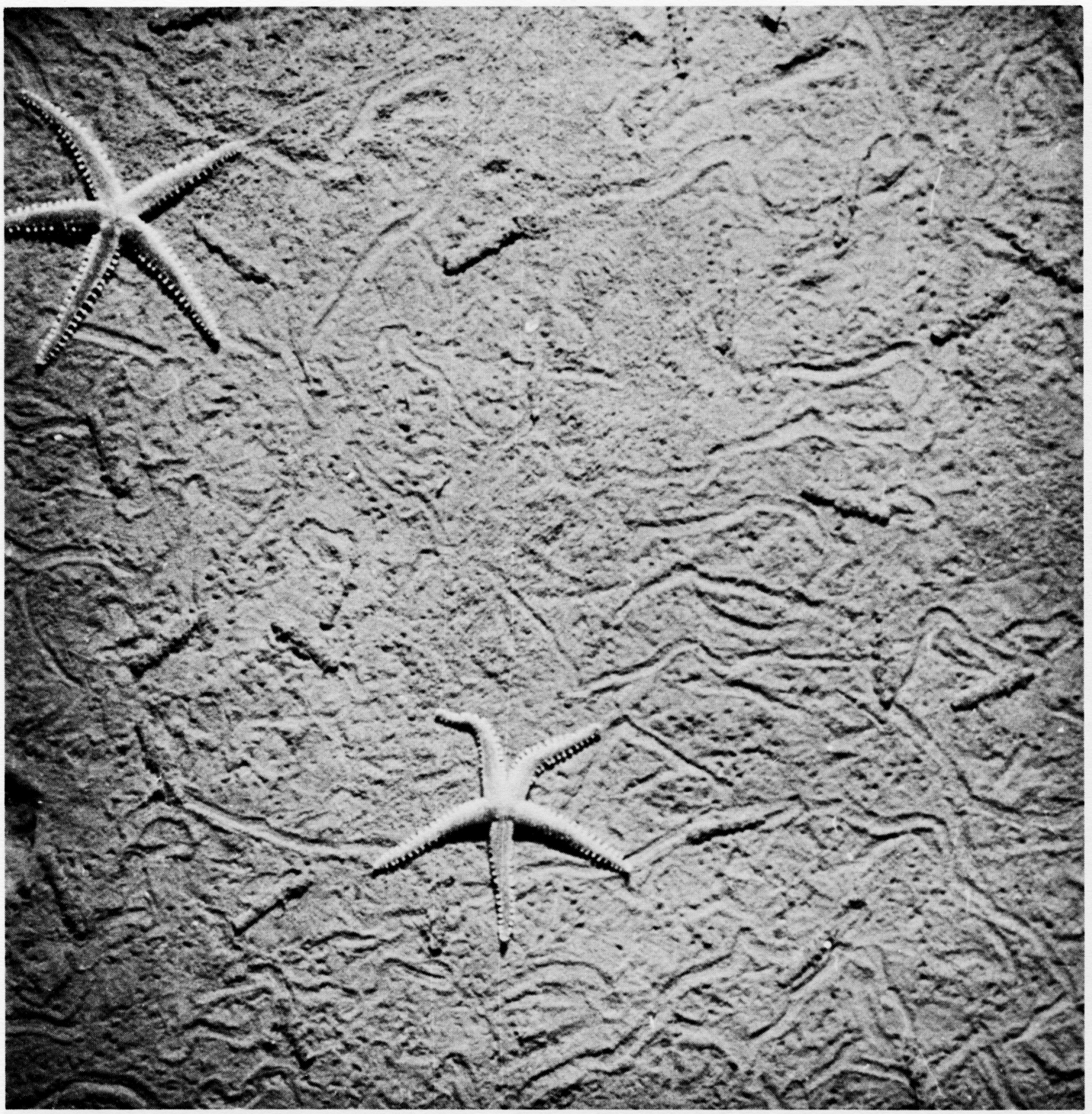




\section{APPENDIX 3}

Station 138 in $104 \mathrm{~m}$. Seafloor covered with several angular rock fragments and some rounded, facetted ice-rafted pebbles and cobbles. One large boulder about 70-80 cm in diameter has been dropped on finer sediments. This boulder is typical of glacially derived sediments. Some rock fragments and pebbles are covered with sand, although the opposite sides appear to be areas of current scour. Such current scour has occurred near the lower right-hand side of the large boulder, where mud has been removed (or not deposited) and a fine gravel appears as a lag. These deposits suggest currents flowed in a direction from top to bottom of photo. Many brittle stars (12-15 cm in length) are seen, as well as a sea urchin (strongytocentratus) on the boulder.

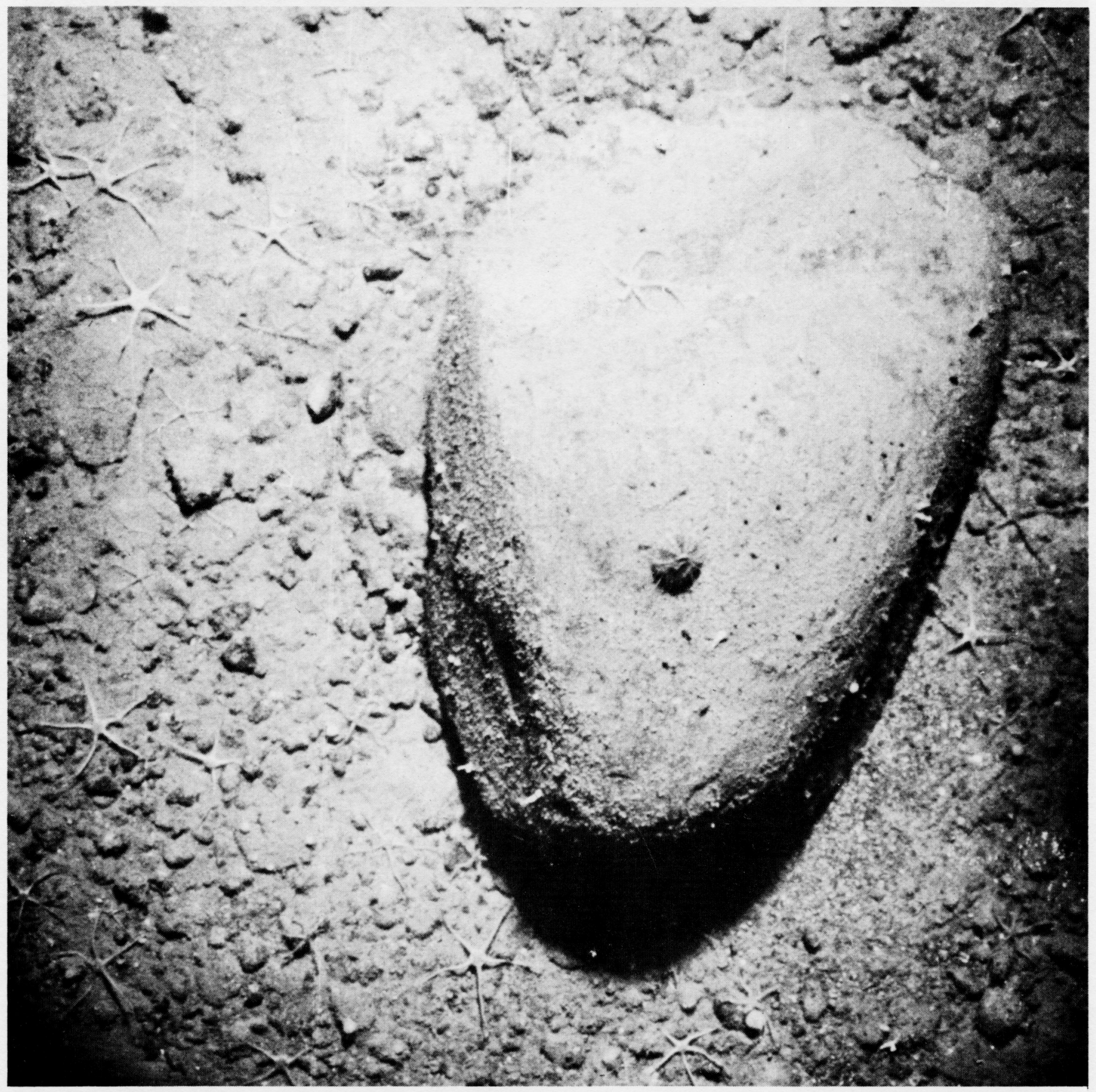




\section{APPENDIX 4}

Station 166 in $75 \mathrm{~m}$. Seafloor covered with considerable ice-rafted pebbels and cobbles. Finer sediment covers part of the coarse detritus, while the opposite side (toward lower end of photograph) shows evidence of current scour. Brittle stars (ophiuroids) and crinoids are common. Crinoid stalks are bent in the direction toward the lower left-hand corner of the photograph, in response to the pressure exerted by flowing bottom currents. Because a compass was used on this photographic survey, this current direction could be recorded. Note that the direction of sediment transport appears to coincide with the direction of the bent crinoid stalks.

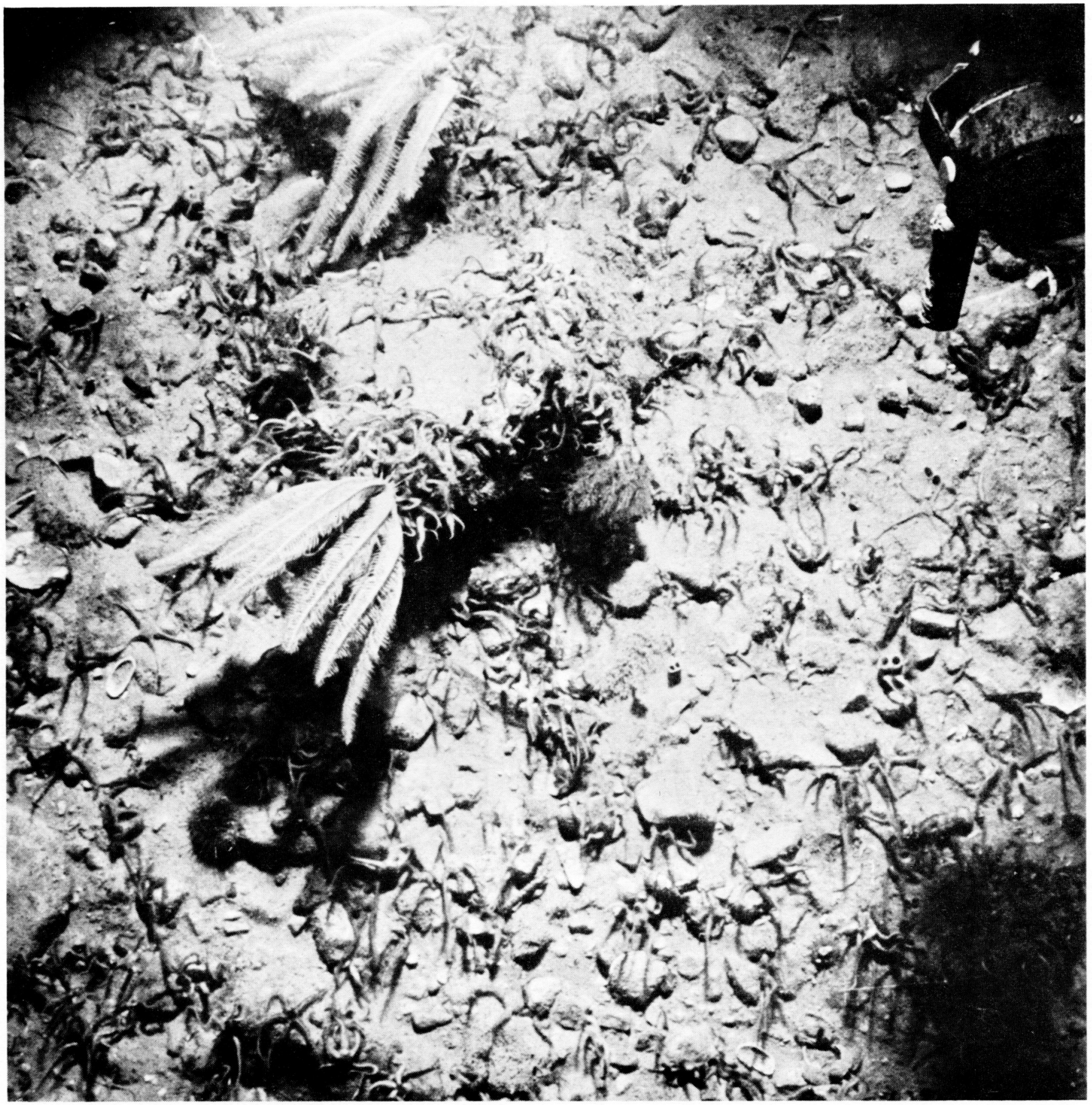


APPENDIX 5

Station 138 in $104 \mathrm{~m}$. A stereogram pair of seafloor photographs (see Appendix 2 for explanation). Note the sea urchin on the boulder.
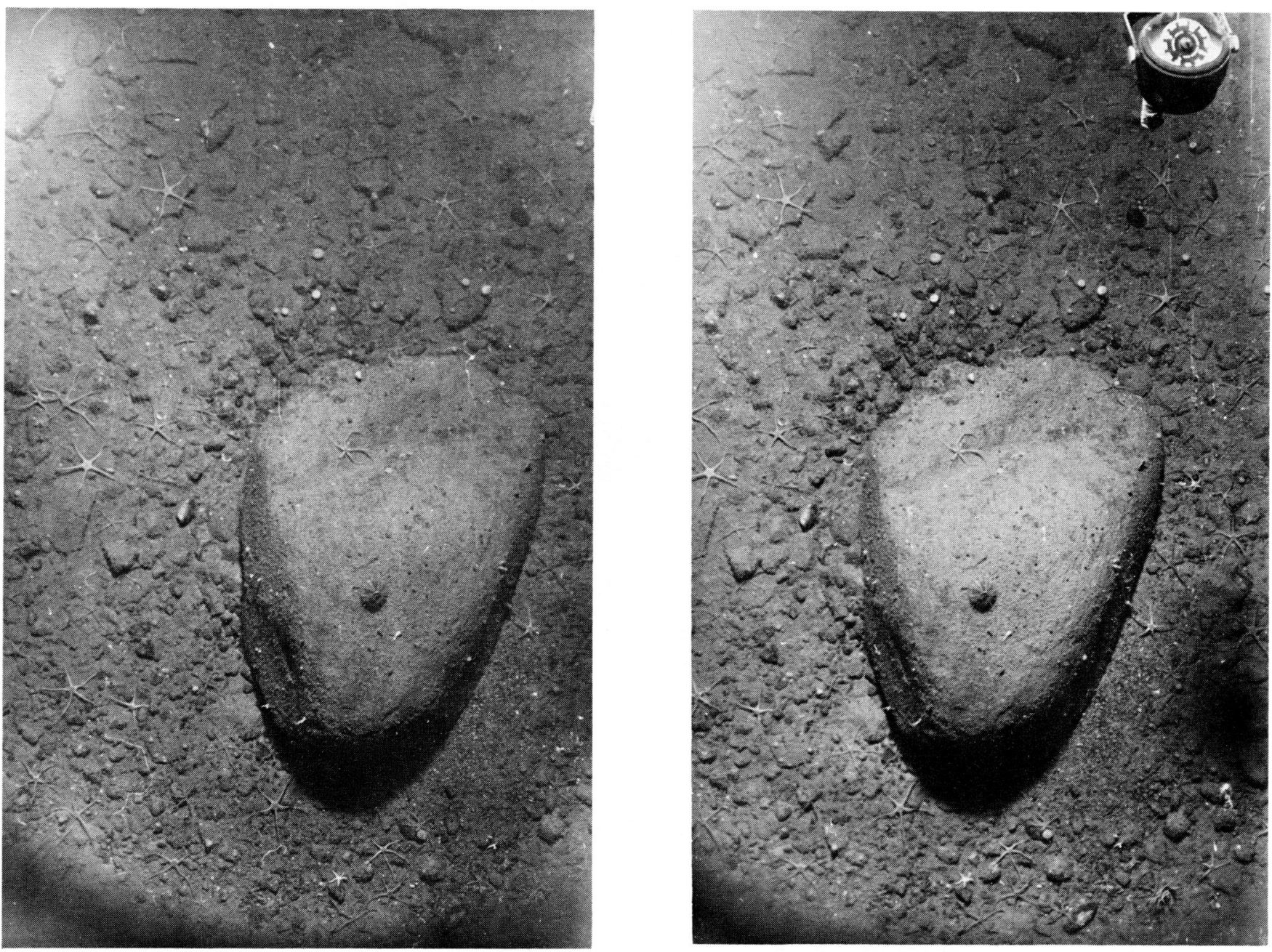


\section{APPENDIX 6}

Station 138 in $104 \mathrm{~m}$. A stereogram pair of seafloor photographs. Large rock fragment is a portion of a Precambrian stromalolitic carbonate outcropping on the Belcher Islands. Other smaller angular rock fragments are present indicating a local origin, although some transport by means of ice rafting has taken place. Numerous glacially derived pebbles and cobbles are present and are indicated by their characteristic rounded edges and facetted shapes. Sediment covers a portion of the pebbles and fragments, while their opposite ends show evidence of current scour where they are in contact with the seabed. This suggests bottom currents moved in a direction down from the top left-hand corner to the bottom right-hand corner of the photographs. This direction can be recorded from observations of the compass needle shown in the right-hand photograph.
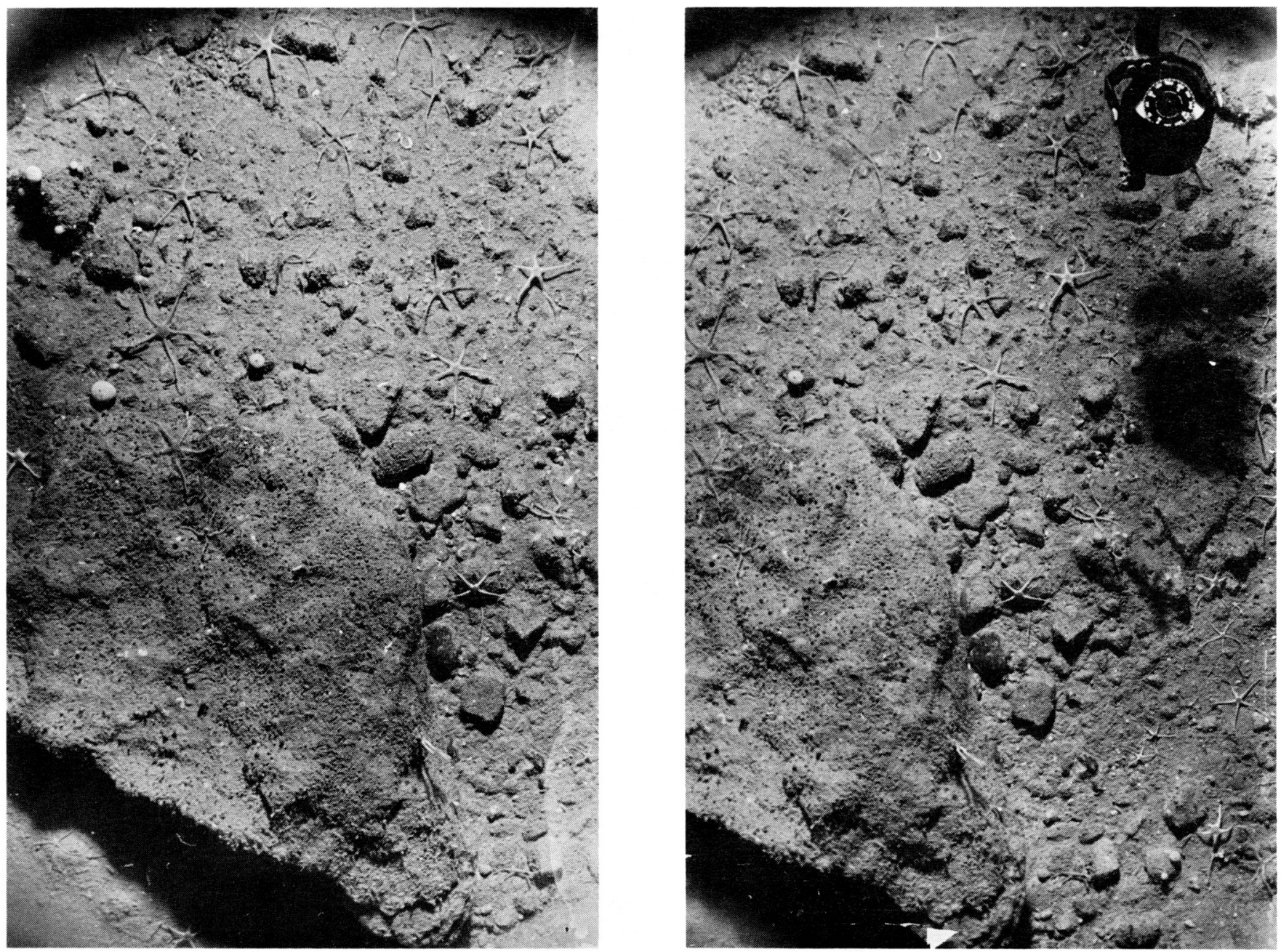


\section{APPENDIX 7}

Station 138 in $104 \mathrm{~m}$. Large angular block and numerous angular, as well as facetted cobbles (ice-rafted) on seabed. Both types of starfish present: ophiuroids and a single asteroid near right-centre part of photograph. Clusters of rock debris such as that seen at the tip of the large block, resemble spawning nests.

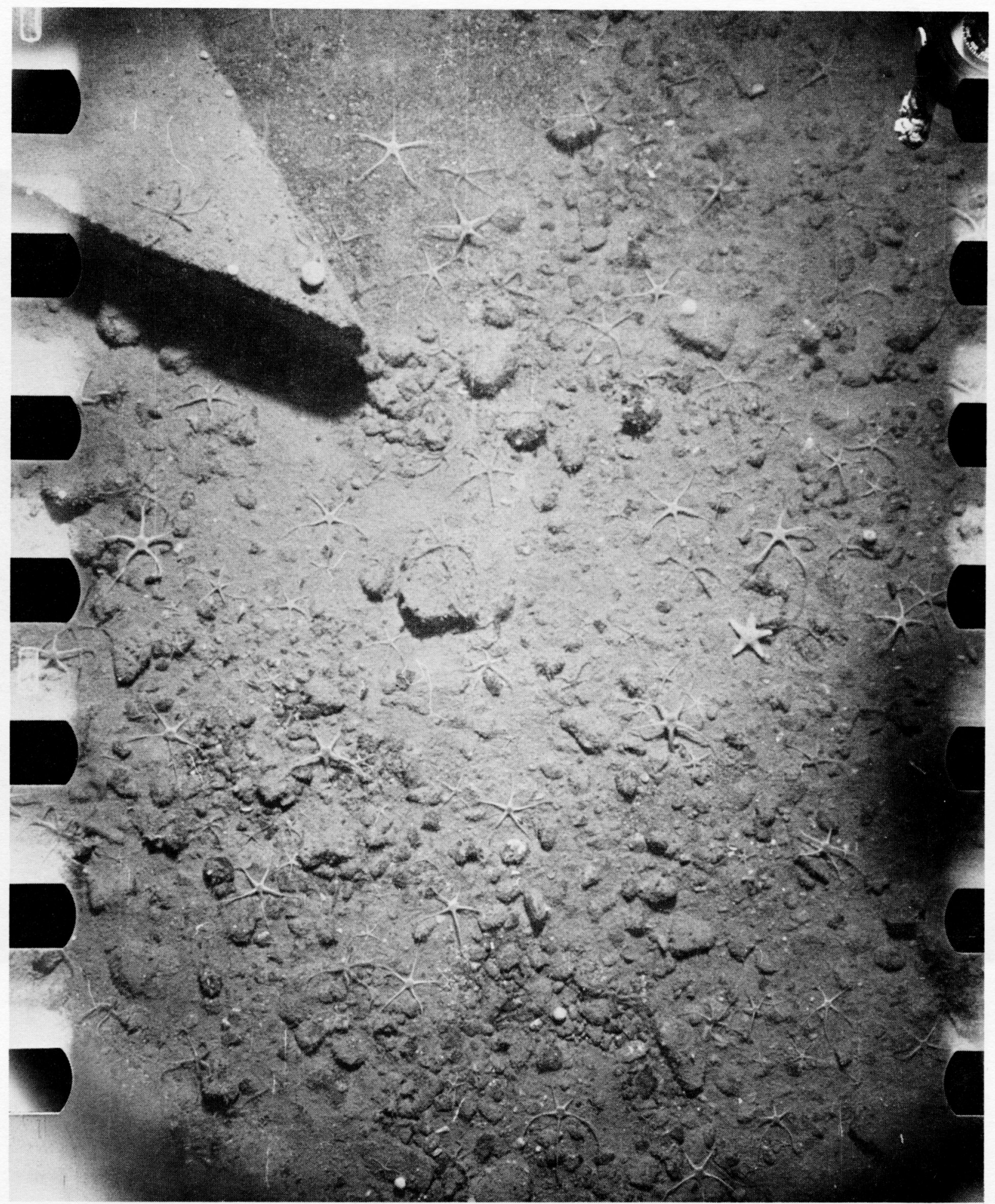




\section{APPENDIX 8}

Station 138 in $104 \mathrm{~m}$. Large ice-rafted boulder and angular blocks cover the seabed. Numerous brittle starfish (ophiuroids) present. Cluster of rock debris near left-centre of photograph may be a nest.

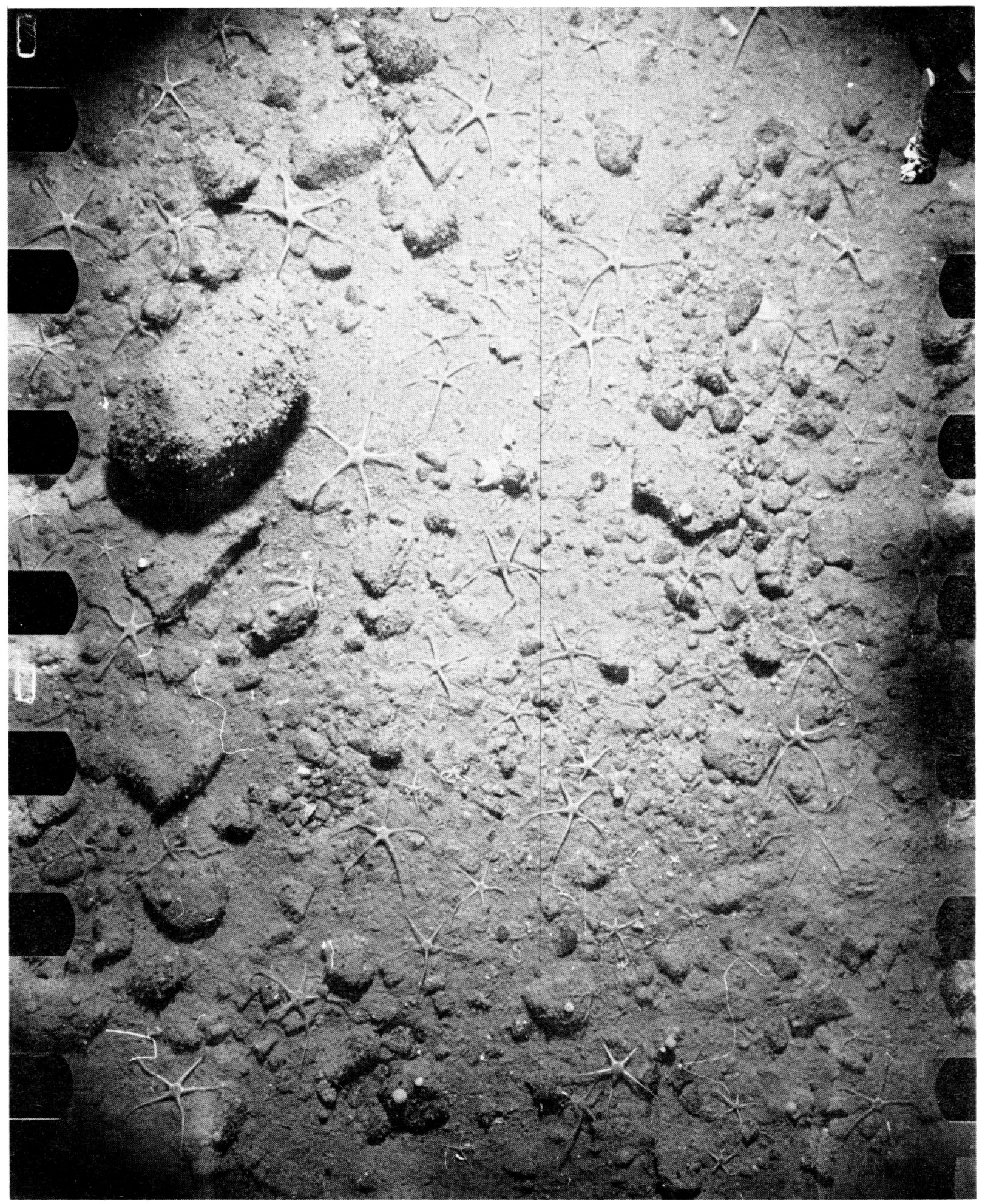


APPENDIX 9

Station 138 in $104 \mathrm{~m}$. Seabed is similar in composition to that shown in App. 6 and 7. Cloud of fine sediment caused by impact of compass strut on seabed during camera-lowering operation. Most cobbles are covered with silt, indicating that fine sediments are depositing in the area but rather slowly.

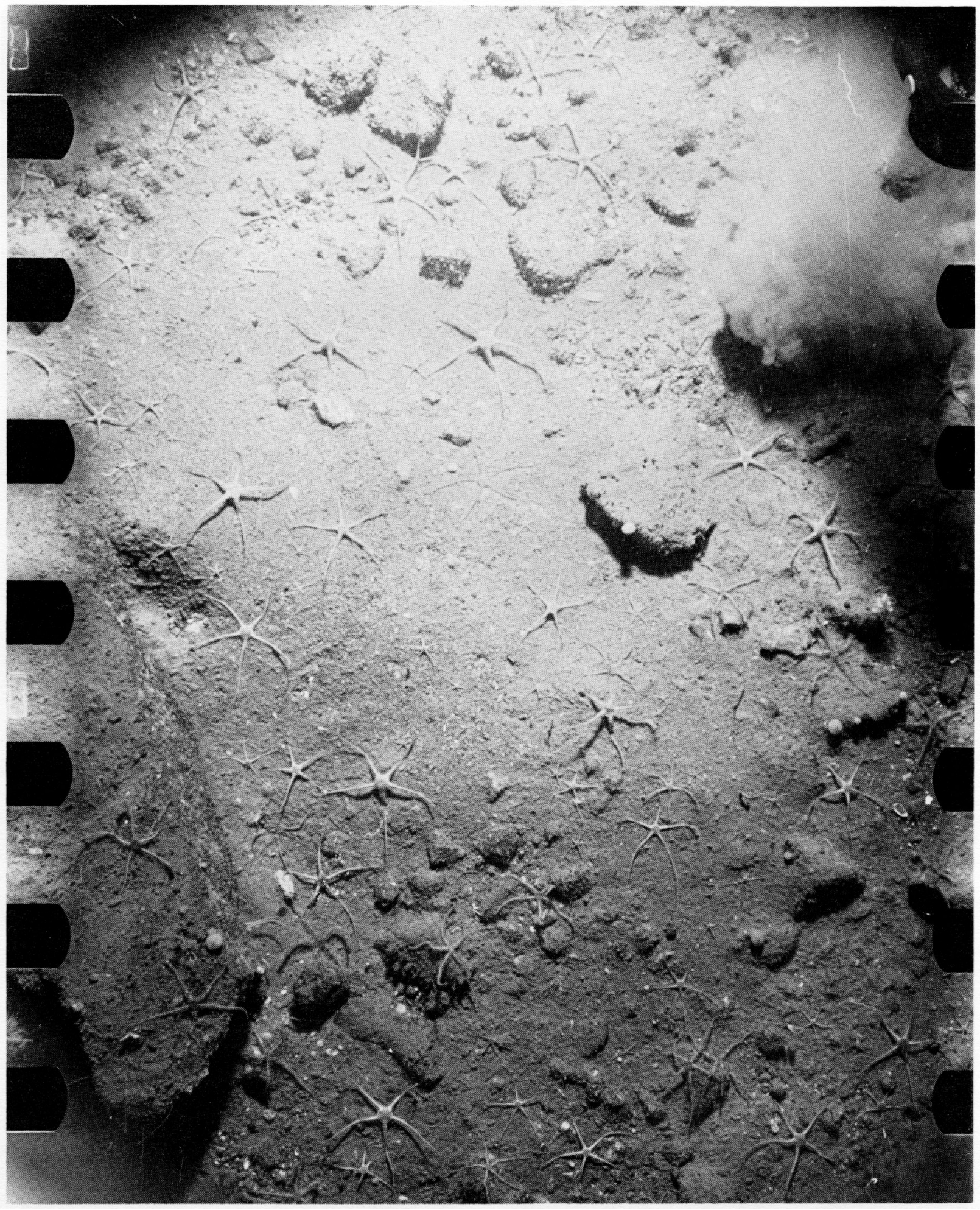


APPENDIX 10

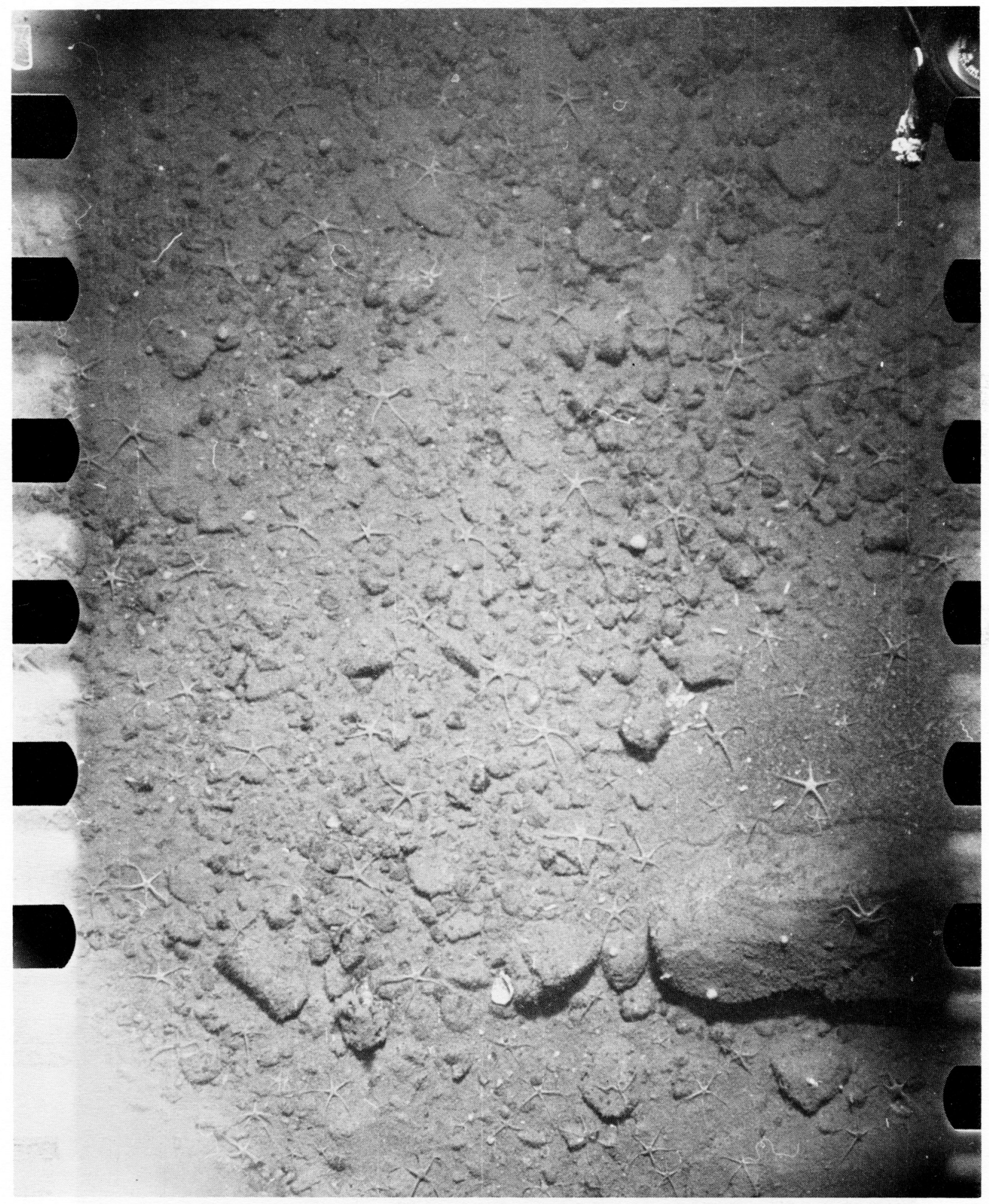




\section{APPENDIX 11}

Station 196 in $55 \mathrm{~m}$. Location is Omarolluk Sound in hydrodynamically quiet water. Sediment substrate consists mainly of fine material such as clay and silt. A shrimp lies on the bottom (right-central part of photograph). An ophiuroid and two anemones are present as seen in lower half of photograph.

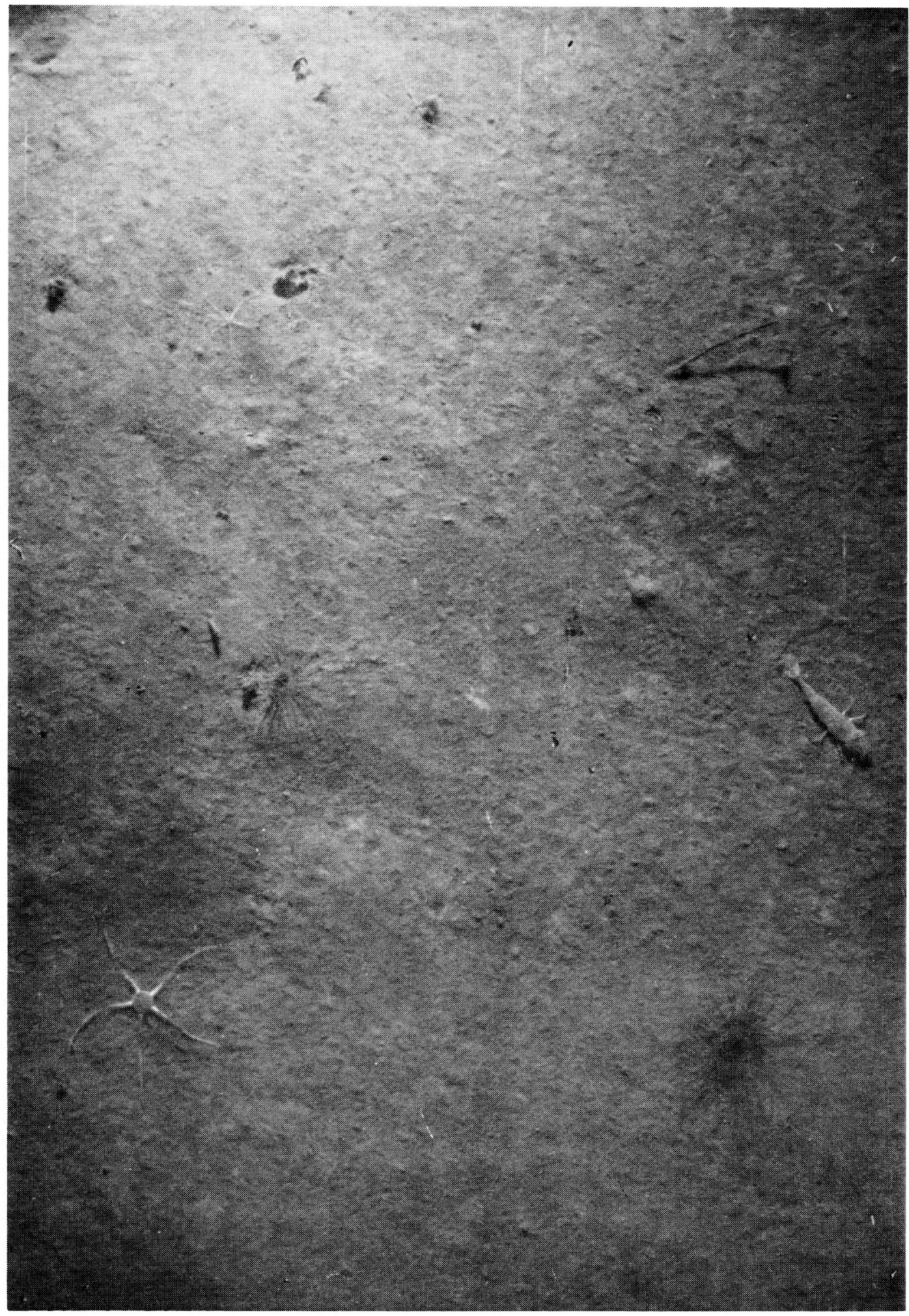


APPENDIX 11 (continued)

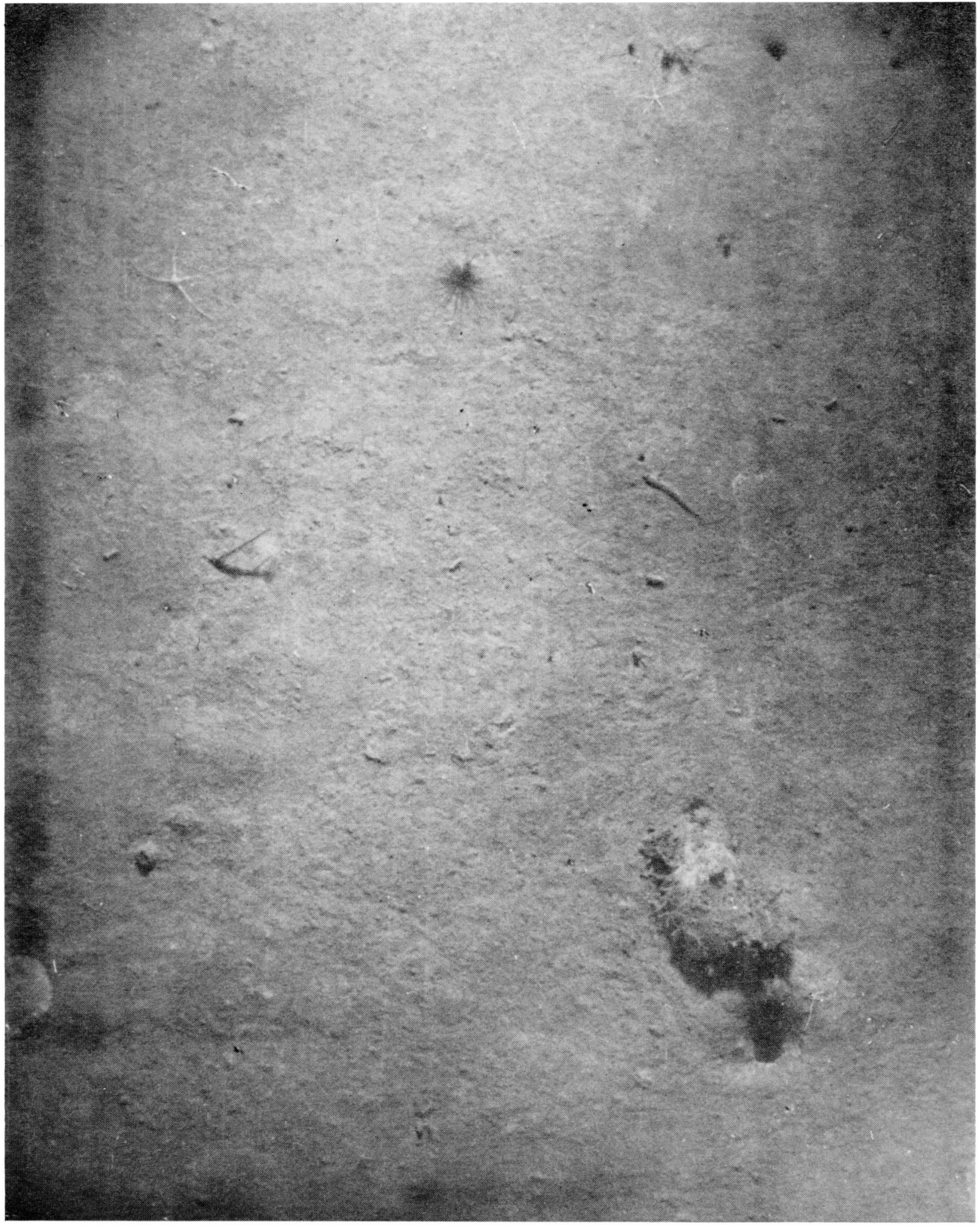




\section{APPENDIX 12}

Station 196, Omarolluk Sound, in $55 \mathrm{~m}$. See App. 11 for substrate description. A few ophiuroids and anemones are present, and possibly a shrimp (top-centre) and a worm (right-centre). Quiet deposition is indicated by the collective absence of coarse sediment, scour, and wave-built features.

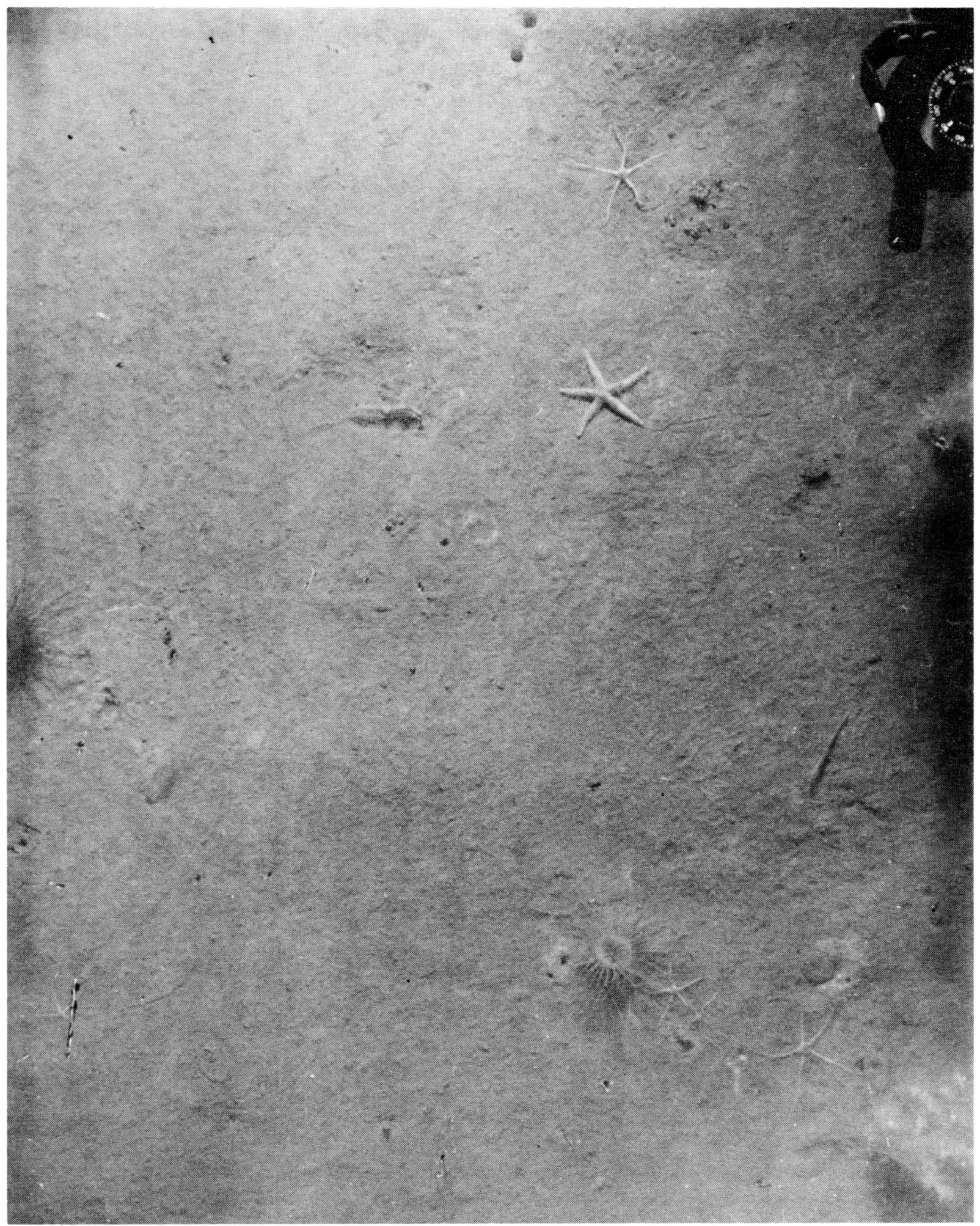


APPENDIX 12 (continued)

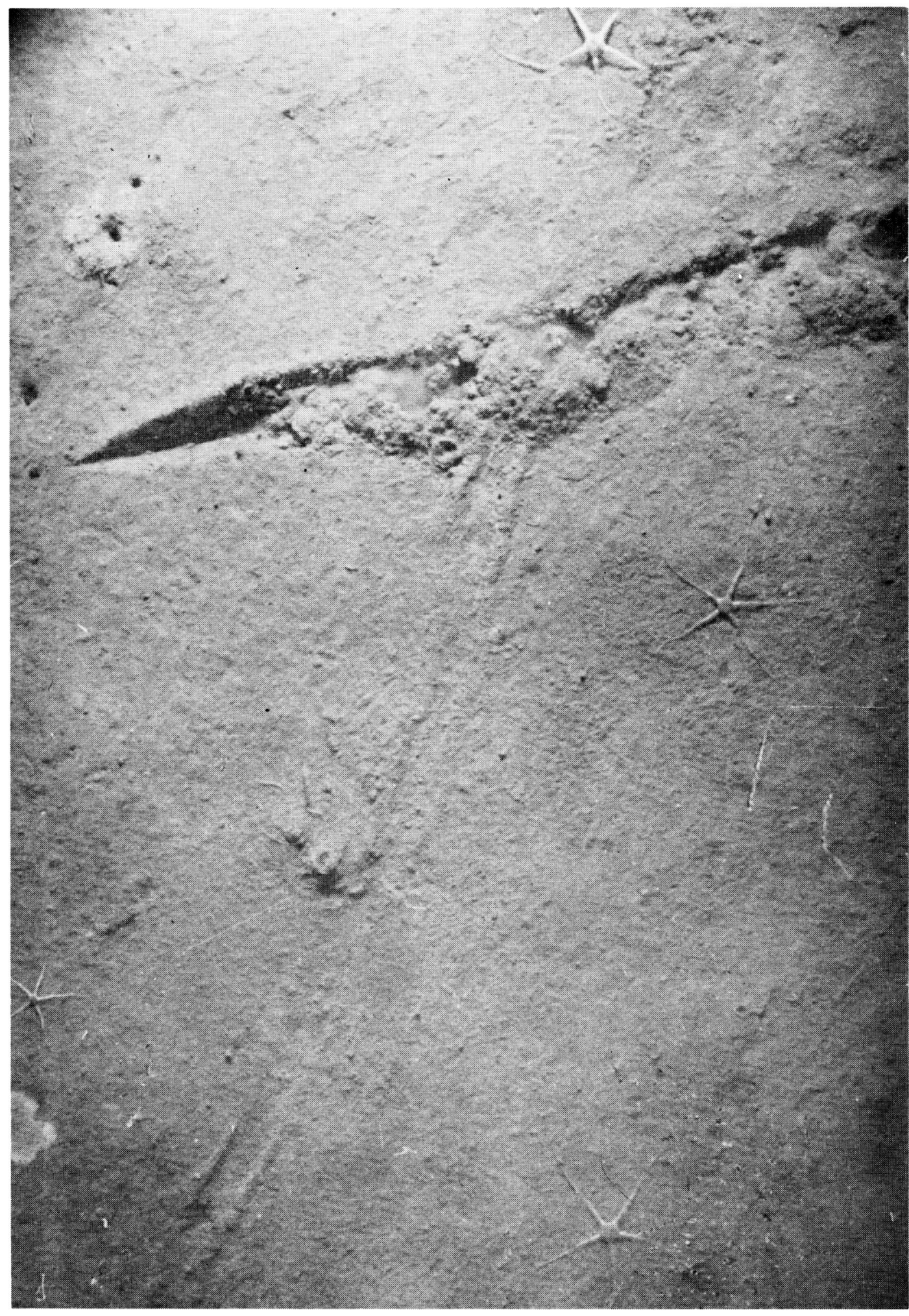




\section{APPENDIX 13}

Station 130 in $183 \mathrm{~m}$. Photograph taken in one of the deepest parts of Hudson Bay. Substrate consists of fine sediments (clay and silt), that deposited under hydrodynamically quiet conditions. Lack of scour and wave-built structures indicate presence of low-velocity bottom currents. Numerous animal trails and worms are present.

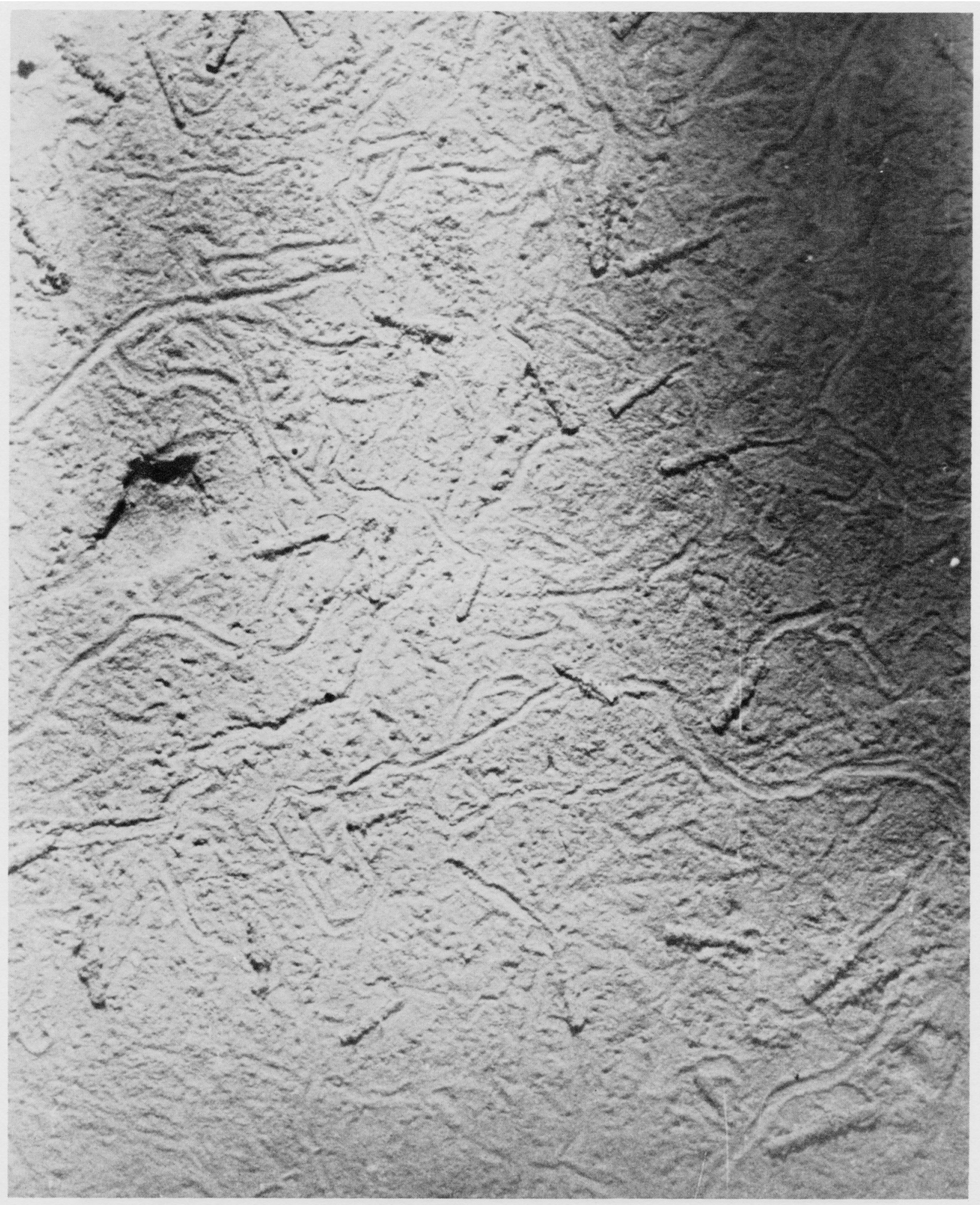




\section{APPENDIX 14}

Station 130 in $183 \mathrm{~m}$. See Appendix 13 for description of substrate and bottom conditions. Left-hand photograph shows numerous animal trails, worms, burrow holes, and a sea urchin. Right-hand photograph shows animal trails and, worms, and two little starfish (ophiuroids).
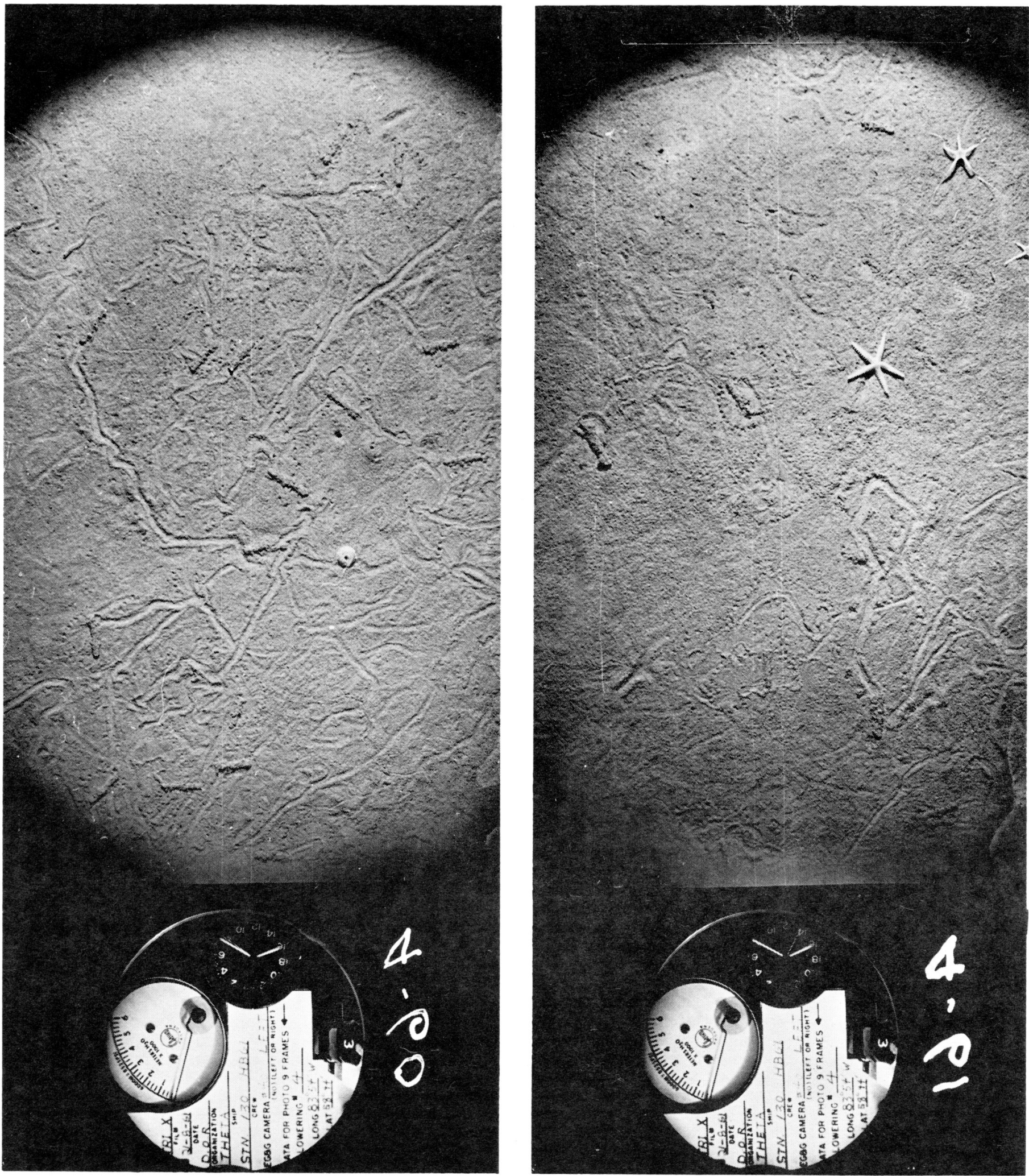


\section{APPENDIX 15}

Station 130 in $183 \mathrm{~m}$. A stalked animal is fastened to substrate of soft sediment. Numerous sea urchings are in immediate vicinity. A small crab is seen in upper part of photograph near a cluster of eggs cases of molluscs.

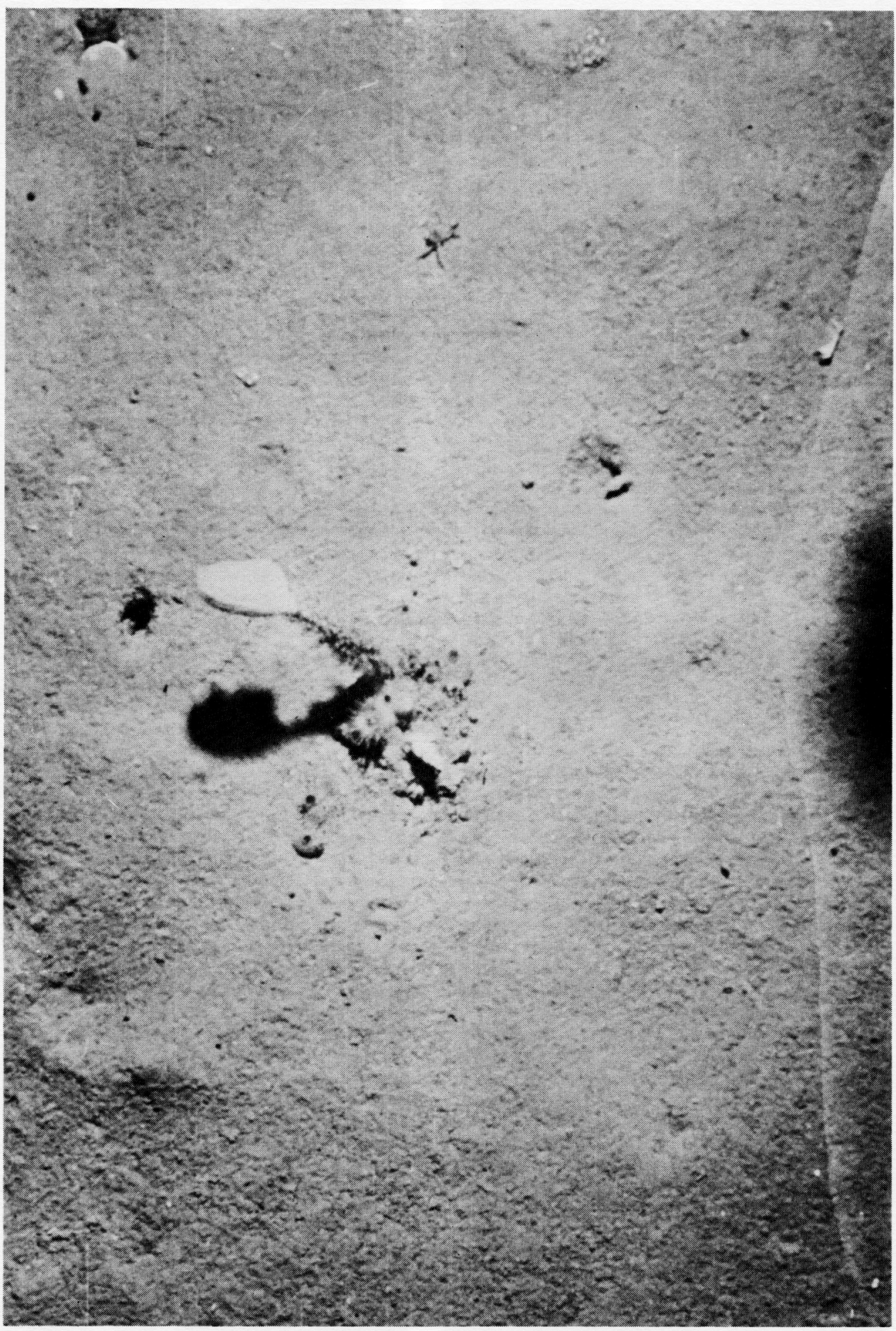

